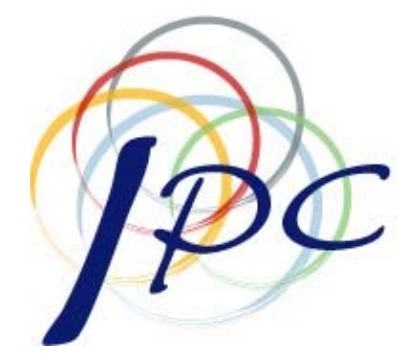

InTERnational Policy Center

Gerald R. Ford School of Public Policy University of Michigan

IPC Working Paper Series Number 39

Is There a Glass Ceiling in Morocco? Evidence from Matcher Worker-Firm Data

Christophe J. Nordman

Francois Charles Wolff

February 2007 


\title{
Is there a glass ceiling in Morocco? Evidence from matched worker-firm data ${ }^{\#}$
}

\author{
Christophe J. Nordman ${ }^{*}$ François-Charles Wolff $^{* *}$
}

February 2007

\begin{abstract}
According to the glass ceiling hypothesis evidenced in developed countries, there exist larger gender pay gaps at the upper tail of the wage distribution. In this paper, we investigate the relevance of a glass ceiling effect in Morocco using a matched worker-firm data set of more than 8000 employees and 850 employers. We estimate linear and quantile earnings regressions which account for firm heterogeneity and perform a quantile decomposition. We also focus on the within-firm gender earnings gap using information on the firms' characteristics. Our results show that the gender earnings gap is higher at the top of the distribution than at the bottom in Morocco. The gender gap widens in the upper tail of the earnings distribution when controlling for firm specific components. The glass ceiling effect is also reinforced over time in Morocco as high wage male workers benefit from higher earnings growth than women.
\end{abstract}

JEL Classification: J24, J31, O12

Keywords: Gender wage gap, glass ceiling, quantile regressions, matched worker-firm data

\footnotetext{
\# We are indebted to Jackline Wahba, our discussant at the $13^{\text {th }}$ ERF Conference, for her very helpful comments on a previous draft. We also would like to thank participants at the DIAL seminar in Paris, at the IZA/World Bank Conference on employment in developing countries in Berlin, at the 23èmes Journées de Microéconomie Appliquée in Nantes, and at the ERF Conference held in Koweit for suggestions and remarks. The usual disclaimer applies.

${ }^{*}$ Corresponding author. IRD, DIAL, 4 rue d'Enghien, 75010 Paris, France.

E-mail: nordman@,dial.prd.fr

** LEN, Faculté des Sciences Économiques, Université de Nantes, BP 52231 Chemin de la Censive du Tertre, 44322 Nantes Cedex 3, France; CNAV and INED, Paris, France.

E-mail: wolff@,sc-eco.univ-nantes.fr http://www.sc-eco.univ-nantes.fr/ fcwolff/
} 


\section{1/ Introduction}

Almost every industrialised countries labour market is characterised by a significant gender pay gap (Altonji and Blank, 1999). This is the case for instance in Europe, despite of laws mandating an equal treatment of women and men in the workplace. Not only female and male employees do not receive equal pay for equal work, but it has more recently been shown that the gender wage vary in fact throughout the wage distribution. Albrecht et alii (2003) exhibit a sharp acceleration of the gap in the upper tail of the wage distribution in Sweden, which is interpreted as a glass ceiling effect. Very similar conclusions have been evidenced in many European countries (Arulampalam et alii, 2004, Gardeazabal and Ugidos, 2005).

While there is a consensus on the fact that men outearn women, measuring the gender wage gap across the wage distribution is far from being straightforward. A first difficulty is that many women do not take part in the labour market, so that sample selection issues may be of importance. Secondly, the type of sector or of firm is likely to play a major role in explaining variations in individual earnings. Matched worker-firm data are then ideally needed to study the gender pay gap, since such data allows controlling for unobserved heterogeneity at the firm level on earnings differentials (Meng, 2004, Meng and Meurs, 2004).

In developing countries, reducing gender inequality is a major subject of concern in the fight against poverty. For instance, under the Poverty Reduction Strategy Paper (PRSP) initiative that concerns over sixty of the world's poorest countries, policies designed to counter gender discrimination are among the most often recommended solutions to combat poverty (see Cling et alii, 2003). Furthermore, the third goal of the Millennium Development Goals (MDG) is aimed at reducing gender inequalities. Despite of the policy implications related to gender discrimination, empirical studies which have attempted to measure the gender pay gap in developing countries are not so frequent.

Appleton et alii (1999) note that there is undeniably very little literature on the gender pay gap in Africa. Drawing on the recent meta-analysis of studies on the gender pay gap presented in Weichselbaumer and Winter-Ebmer (2005), we can evaluate that about 3 percent of these studies stem from African data out of all the empirical literature on the topic since the 1960s. The situation is even worse when turning to distributional approaches of the gender pay gap in developing countries. Some exceptions are Montenegro (2001) on Chile, Mwabu and Schultz (1996) on South Africa and Said (2003) on Egypt. More recently, Fafchamps et alii (2006) have analysed the gender effects on wages in African manufacturing. However, the focus of this valuable comparative study is on the mean values of male and female wages.

The purpose of our contribution is to investigate the gender pay gap along the whole 
wage distribution using a unique matched employer-employee data set from Morocco. In that country, the progress of labour earnings has remained very limited over the recent period, owing to the poor economic context. Skills of the local labour force remain very limited, especially for women, a phenomenon which is likely to lead to increased gender pay inequalities in the upper part of the earnings distribution. The survey is the Firm Analysis and Competitiveness Survey (FACS) conducted in 2000 by the World Bank and the Moroccan Ministry of Trade and Industry. It includes data from 859 manufacturing plants. Most of them are small and medium sizedenterprises. The worker survey includes data from 8375 workers, 40 percent of which are women.

We follow different steps to study whether there exists a glass ceiling effect in these manufacturing firms of Morocco. First, we estimate quantile regressions on the whole sample of workers (male and female) and investigate how the gender pay gap varies across the earnings distribution once we control for individual characteristics. Second, we try to control for firm specific effects. Drawing on a component principal analysis, we summarize the main information on the firms' characteristics and introduce the computed principal factors stemming from this analysis into the earnings functions. Third, we analyse the extent to which returns to exogenous factors differ between men and women.

We also provide additional evidence on the gender wage gap and on the factors that influence firms to pay different premia for men and women. On the one hand, we implement both mean and quantile decomposition of the log gender earnings gap following ${ }^{1}$. On the one hand, we focus on the log wage growth within the firm for each worker and examine whether male and female employees receive a similar treatment. We also go back to the mean values of the wage gap and compute the difference between the male and female firm fixed effects. This difference in fixed effects allows us to disentangle the determinants of the within-firm gender earnings gap (Meng, 2004). All these various analyses are made possible for the first time in the context of an African country, thanks to the availability of the very rich firm-level information.

Several interesting features of wage determination process in manufacturing firms of Morocco are evidenced in the present contribution. First, as in many developed countries, we evidence a glass ceiling effect in Morocco since the earnings gap is substantially higher at the top of the distribution than at the bottom. Second, as shown by the quantile decomposition, a large part of the gender earnings gap is due to differences in individual characteristics, especially at the top of the wage distribution. Third, it matters to account for firms' characteristics as the gender

\footnotetext{
1 The difference between the male and female earnings distribution is decomposed into one component due to differences in labour market characteristics and one related to disparities in rewards for these characteristics.
} 
earnings gap is increased when adding the firm features into the earnings regressions, especially in the upper tail of the earnings distribution. Finally, we find that high wage male workers benefit from higher earnings growth than women.

The remainder of our paper is organised as follows. In Section 2, we briefly review the literature on the glass ceiling effect. In Section 3, we present the FACS data and comment on the descriptive statistics of the samples of firms and workers. We present the results from various linear and quantile regressions of the log earnings in Section 4. Additional issues dealing with quantile decomposition, wage growth and difference in firms fixed effects are in Section 5. Finally, Section 6 concludes.

\section{2/ Gender wage gap and glass ceiling effect: A brief review}

Drawing on Swedish data from 1998, Albrecht et alii (2003) estimate quantile regressions and find that the gender log wage gap accelerates in the upper tail of the wage distribution. A similar pattern is evidenced at the beginning of the 1990s, but not in the prior two decades. According to the data, the wage pattern is mainly due to gender differences in the returns to labour market characteristics, more than to gender differences in the characteristics themselves. Several studies have attempted to replicate these findings in other European countries.

In West Germany, the gender wage gap has narrowed substantially in the lower part of the wage distribution from 1975 to 1995, while this is not the case in its upper part (Fitzenberg and Wunderlich, 2001). In Denmark, the wage gap exhibits an insignificant narrowing at the bottom of the wage distribution, then a small and significant increase at the mean, finally a large and significant rise at the top (Datta Gupta et alii, 2006). In Spain, gender wage differences increase with the quantile index, the gap reaching a maximum at the ninth decile (Gardeazabal and Ugidos, 2005). However, it is strongly affected by education (De la Rica et alii, 2005)².

A more comparative analysis is proposed in Arulampalam et alii (2004), who estimate quantile regressions to investigate how gender affects the shape of the wage distribution in eleven European countries, respectively for the private and public sectors. Their results show that gender pay gaps are larger at the top of the wage distribution in four countries, Denmark, Finland, Italy and the Netherlands, which favours the glass ceiling hypothesis. At the same time, gender pay gaps are wider at the bottom of the wage distribution in Austria, Belgium, France and Spain, but they are all the same larger at the top than at the bottom of the distribution. Also, in

\footnotetext{
2 On the one hand, the gap is wider at the top than at the bottom for workers with high education (college or tertiary). Conversely, the gap appears much smaller at the top than at the bottom of the distribution for the group with low education. This glass floor pattern is interpreted as a statistical discrimination exerted by employers.
} 
contrast to the public sector, the private sector exhibits very large wage gaps.

Taking firm characteristics into account may be relevant when estimating the gender wage gap. Jellal et alii (2007) use a French employer-employee matched data set and provide quantile estimates of the magnitude of the glass ceiling effect, with controls of the firms' features in the earnings equations. These authors find that there exists a glass ceiling effect in France with a strong increase in the gender earnings gap above the $75^{\text {th }}$ percentile of the distribution, which is mainly due to differences in the returns to observed characteristics. Importantly, the magnitude of the gender gap is significantly overstated at the top of the distribution when the impact of the firms' qualitative aspects is omitted into the earnings equations.

Economists have not really paid attention to the situation of the African countries with respect to the glass ceiling effect. The few studies that have attempted to deal with the gender wage gap in Africa have mainly focused on its magnitude evaluated at the mean of the wage distribution ${ }^{3}$. Among them, however, the study of Fafchamps et alii (2006) is of particular interest since these authors make use of matched employer-employee data from eleven African countries, including the survey on Morocco we use in this paper. A significant gender wage gap is found in the different selected countries ${ }^{4}$.

Nevertheless, once controls for firm heterogeneity are introduced, the magnitude and significance of the gender dummy in earnings equations fall in most countries. This suggests that the gender wage gap may be due in large part to sorting among firms. While on average the return to education is higher for women, the difference is not significant in seven of the eleven countries. In three countries, women get paid less than men on average, but the gap is lower for educated women and it even disappears for women with ten to twelve years of education. So, Fafchamps et alii (2006) conclude that "women must be better educated in order to compete with men for better paid jobs, perhaps because of statistical discrimination". This seems at odd with the glass ceiling phenomenon observed in industrialised countries.

Interestingly, Morocco tells a somewhat different story as compared to the other African countries (Fafchamps et alii, 2006). The return to education is significantly higher for males, while the female dummy in the earnings function is positive for women with very little education. At higher levels of education (above three years of schooling), women get paid less than men. Also, gender differences in the education coefficient are no longer significant once controls for

\footnotetext{
${ }^{3}$ See Nordman and Roubaud (2005) for a review.

4 These countries are Algeria, Burundi, Cameroon, Côte d'Ivoire, Ethiopia, Ghana, Kenya, Morocco, Tanzania, Zambia, and Zimbabwe.
} 
occupation and firm heterogeneity are introduced ${ }^{5}$. Importantly, the focus remains on the mean values of male and female earnings, whereas a distributional approach is undoubtedly needed to disentangle the various forces at work in the earnings determination process across sexes.

\section{3/ Description of the data}

\section{1/ The Moroccan context}

Morocco is a semi-developed economy characterised by a rapidly evolving working population. While the job seekers are abundant, the skills of the Moroccan labour force are limited. More than 50 percent of adults are illiterate, this proportion being much higher for women (70 percent). During the last decade, social indicators substantially improved due to growth in public social expenditure and focus on rural areas (World Bank, 2001). Yet, poverty and vulnerability were found to be on the rise. The morose economic context during the 1990s, the period referred to in this article, hampered the progress of labour earnings.

The labour legislation underpins the level of wages in Morocco. Unions have a strong influence and there exists an official minimum wage, the so-called SMIG (Salaire Minimum Interprofessionnel Garanti). The latter has played a crucial role for the formation of wages in the recent period. This has not always been the case since real wages of the Moroccan manufacturing sector declined, while the real SMIG increased by about 25 percent during the 1980s. During the 1990s, the distribution of wages roughly stuck to the evolution of the SMIG. More precisely, the SMIG adjustments over time rather followed the evolutions of the mean urban wage more than proportionally (World Bank, 1994). If the minimum wage is not effectively enforced in the informal sector of the economy, it is well implemented throughout the industrialised and unionised sectors in which most workers' earnings stand above the minimum wage ${ }^{6}$. These workers are generally paid between 13 and 16 months salary, including bonuses, each year.

Despite the importance of this country in the Mediterranean region, only a few articles deal with the functioning of the labour market in Morocco. Undoubtedly, the reason is the lack of appropriate data. Noticeable exceptions are the studies of Lane et alii (1999) and Agenor and El Aynaoui (2003). The former underlines the stagnation of the average wage in the manufacturing sector over the 1990s. Considerable gaps in average wages persist across sectors. The least remunerative industrial sectors are those of leather and confection, while the most

\footnotetext{
${ }^{5}$ However, possible nonlinearities in the returns to education are not considered, while the hypothesis of constant returns is increasingly challenged especially in developing countries. In Africa for instance, returns to education are most often found to be convex (Söderbom et alii, 2004, Kuepie et alii, 2006).

${ }^{6}$ According to Benhayoun et alii (2001), only 13 percent of the wage earners in the private formal sector are unfairly paid a salary lower than the minimum wage.
} 
profitable are the sectors of drinks and tobacco. In 1995, the average wage in the latter sectors was more than three times higher than that of the confection sector. Also, most women work in low paying sectors, such as textiles and leather. The stagnation of wages may be partly explained by the fact that the least remunerative industries have had the biggest part of job creation during the past decade. Skills of the workforce and exposure to competition explain wage disparities across sectors (Clerides et alii, 1998) ${ }^{7}$.

Until recently, working relations were governed by legislation dating back to 1921, with emphasis on job security. It was, in particular, very expensive to dismiss permanent workers. The law provided for a 48-hours maximum workweek with no more than 10 hours any single day, premium pay for overtime, paid public and annual holidays, and minimum conditions for health and safety, including the prohibition of night work for women and minors. However, these norms are not universally observed in the informal sector. Nowadays, the labour market may benefit from the recently adopted labour code (July 2003), which encourages flexibility and contains procedures for conciliation. The new code also reflects international conventions regarding the protection of children, women, handicapped people, and workers and unions' rights.

To date, there is a lack of empirical evidence on the extent of gender wage differentials in Morocco, which is the primary interest of this paper. To fill in this gap, we benefit from detailed data on both firms and workers. This allows us to control for firm-specific effects on earnings differentials. Also, the use of a distributional approach sheds light on differences in gender inequality between low wage and high wage workers.

\section{2/ The FAC Survey}

The objective of the Firm Analysis and Competitiveness Survey (FACS hereafter) was to strengthen capacity in the Moroccan Ministry of Trade and Industry to systematically collect and analyse data from manufacturing firms using a wide ranging questionnaire. More specifically, the FACS was designed to provide the Government with a quantitative tool to monitor industry performance, provide firms with a checklist of competitive practices and benchmark indicators, and foster Business-Government dialogue by measuring the impact of reforms and refocusing the agenda on the most relevant and pressing concerns.

\footnotetext{
7 Other factors may play a role, as the employment duration, the seasonal features of jobs and on-the-job training. Legally, the minimum wage is not applied for certain types of employees, such as young workers below 18 years old, temporary workers or trainees. Also, in 1986, at least half of the firms of the Moroccan private manufacturing sector and 40 percent of large companies were paying unskilled workers an average wage lower than the SMIG.
} 
The scope of the survey is comprehensive. The data collected can be used to analyse a variety of issues directly or indirectly related to public policy, such as export incentives and performance, technological improvement, upgrading of human capital and functioning of the labour market, government-business relations, or the pricing and quality of public services for industry. The availability of worker-level data provides an opportunity to investigate the link between firm-level responses to macro policies and the economic fortunes/misfortunes of workers.

The FACS-Morocco is based on the notion that the workplace is the microdata unit where labour supply and demand is resolved. For this reason, FACS-Morocco collected data both on establishment characteristics and on a sample of employees in each workplace (on average 10). The survey instrument was a written questionnaire. The Moroccan Census of Manufactures, which is organised yearly by the Ministry of Trade and Industry since 1985, was used as the establishment sampling frame. The investigators, i.e. the Moroccan Ministry of Trade and Industry and the World Bank, decided to focus on the population of formal establishments with 10 or more employees in seven industries: Electronics, Textiles, Garments, Processed Food Products, Pharmaceuticals, Leather and Shoes products, and Plastic Products.

Conducted between October 2000 and February 2001, the FACS-Morocco collected data from 859 plants, 78 percent of them being small and medium sized-firms ${ }^{8}$. The collected data are representative of the sampling frame - which is the overall manufacturing industry - in terms of employment, production and exportation (see World Bank, 2002). Some descriptive statistics of the firm characteristics are shown in Table 1. 60 percent of the sample firms are located in and around Casablanca, and 60 percent of the plants are in Textile and Garments. 57 percent of the firms are limited liability companies (SARL) and 36 percent are corporations (SA). About 20 percent of the surveyed firms have some foreign ownership; 15 percent have a majority foreign ownership - mostly by foreign individuals. Some 5 percent of surveyed firms can be described as 'multinationals'. 56 percent of the surveyed manufacturing firms export all or part of their output, and exporting firms export on average 43 percent of their output. Note that 62 percent of the firms have positive profits (hereafter 'profitable' firms).

Let us have a look at the firms' labour force. About 13 percent of the surveyed employers declared having unionised employees while the share of these unionised workers reaches, on average, about 10 percent of the total manpower. It is interesting to note that only two firms have implemented piece-rate pay systems for non-qualified employees. Besides, highly

\footnotetext{
8 A random sample of 1000 establishments and a replacement sample of 500 were drawn by industry, the choice of regions being dictated by the geographical concentration of firms in the selected industries.
} 
labour intensive firms with labour costs being superior to 75 percent of the total costs represent only a small proportion of the firm sample (5 percent), while the firms with skilled production employees being the dominant occupation (among four other worker categories such as managers and executives, admin, unskilled production employees, and off-production employees) represent 32 percent of the surveyed establishments. Moreover, 12 percent of the firms display a share of managers higher than 10 percent of the total employees. These figures are indicative of a somewhat decent representation of firms with highly skilled workers in our sample which is crucial in order to assess the relevance of the glass ceiling hypothesis.

\section{Insert Table 1 here}

To test the glass ceiling hypothesis, one novelty of our approach is to control for firm level variables in the analysis of earnings determination. Following Muller and Nordman (2004) and Jellal et alii (2007), our approach consists of summarising the main statistical information on the firms' characteristics using a multivariate analysis and introducing the computed principal components (factors) stemming from this analysis into the earnings functions. Using factors may be seen as a further step with respect to those studies which have added mean firm variables into earnings functions, individual characteristics being controlled for.

By contrast with firms' fixed effects that are commonly introduced in wage regressions, the principal factors suggest qualitative characteristics of the firms. Specifically, we use a principal component analysis (PCA) to summarise the information about the surveyed establishments? This method is based on the calculation of the inertia axes for a cloud of points that represents the data in table format. As long as the computed factors account for most of the firm heterogeneity bias, this approach allows us to obtain consistent estimates of the returns to worker characteristics and of the gender wage gap. The complete list, definitions and descriptive statistics of the firms' characteristics introduced in the PCA appear in Table 1.

For our purpose, the first ten inertia axes (the estimated factors which are linear components of all the firm's characteristics) concentrate a large proportion of the total variance of the original variables (63 percent) and reflect, therefore, a fair amount of the relevant information about the firm's characteristics ${ }^{10}$. The correlation coefficients of the firms' characteristics with the first ten factors are used for the interpretation of the computed factors.

\footnotetext{
${ }^{9}$ In principal component analysis, a set of variables is transformed into orthogonal components, which are linear combinations of the variables and have maximum variance subject to being uncorrelated with one another. Typically, the first few components account for a large proportion of the total variance of the original variables, and hence can be used to summarize the original data. The computed factors were rotated using an oblique rotation. As in Muller and Nordman (2004) and Jellal et alii (2007), we have tried many other techniques of factor analysis, which all lead to similar conclusions.

10 The detailed results of the factor analysis are not reported to save space and are available from the authors upon
} 
The other factors represent a negligible amount of the statistical information and are dropped from the analysis. Let us note that the ten factors are closely associated with the firms' sectoral belonging and size (factors 2, 5, 6, 7 and 9), the firms' performances such as their sales, production and profitability in 1998-1999 (factors 1 and 10), their labour intensity and workforce composition such as whether production, skilled, or executives workers are dominant (factors 3 , 6 and 8), and the firms' general features such as their vocation to export and status of ownership (factors 1 and 4). The ten factors reflect a wide range of firm characteristics that can mainly be summarised by the sector affiliation, size, performances, and workforce composition.

\section{3/Description of the gender wage gap}

The employee survey provides information on 8365 workers, 40 percent of them being women. The workers were randomly chosen in their establishment following the idea advocated by Mairesse and Greenan (1999). The average age of sampled workers is about 34 years old. The average worker interviewed has completed primary school, the number of years of completed schooling being equal to 8.7 .

In Table 2, we describe the worker sample and the main variables that we use in our analysis. We note that men have a slightly higher level of education (8.83 years of schooling instead of 8.55), and their potential experience is much higher, with a gap of about 5 years, which is then explained by the fact that males are on average older than females ( 37 versus 31 years old). In fact, a similar pattern is observed for tenure in the current firm, which is equal to 8.12 years for men instead of 5.98 for women. Also, unsurprisingly, men are more likely to have experienced previous jobs, while women report a lower number of children than men. This may be because having children strongly reduces the labour force participation of women.

\section{Insert Table 2 bere}

As male employees have more experience than female employees, gender differences in earnings are expected in the FACS data. In Table 2, we compute the log monthly earnings both for men and women and report the corresponding values for various points of the earnings distribution $^{11}$. Albeit preliminary, as individual characteristics are not controlled for, these results lead to several interesting conclusions. First, at the mean of the sample, the magnitude of the gender earnings gap is equal to about 24 percent $(7.96-7.72=0.24)$. Second, the gender gap is not constant across the earnings distribution.

request.

11 Note than earnings declared in hours, days or weeks have been converted into monthly earnings using the available information on the usual number of hours worked per week in the questionnaire. 
For instance, at the $5^{\text {th }}$ percentile, the gender earnings gap is only equal to 14 percent and it is even lower at the first decile (10 percent). The profile remains flat till the $25^{\text {th }}$ percentile (11 percent), but it then suddenly increases. Differences between male and female earnings are approximately equal to 20 percent at the median value, which is still less than the mean gender gap. The gap is much higher on the top of the earnings distribution. It is equal to 44 percent at the $75^{\text {th }}$ percentile, 49 percent at the $9^{\text {th }}$ decile, and finally 51 percent at the $95^{\text {th }}$ percentile. In Figure 1, we represent the evolution of the log gender earnings gap along the earnings distribution and add confidence bands measured at the 95 percent level. We observe that the gender gap is relatively constant until the $3^{\text {rd }}$ decile, but sharply increases after that point. Furthermore, this increasing profile is monotonic till higher levels of wage.

\section{Insert Figure 1 here}

Hence, these preliminary findings suggest that it matters to assess the magnitude of the gender earnings gap not only at the mean of the samples, and also that there may exist a glass ceiling in Morocco (at least in the manufacturing sector) as in other more developed countries.

\section{4/ Econometric evidence on the glass ceiling effect}

\section{1 - Evidence on the mean gender wage gap}

We begin by estimating a simple OLS model on the whole sample of men and women. The different variables introduced into the regression are the number of children, years of completed schooling, years of potential experience and years of tenure (with a quadratic profile for the last three variables), number of preceding jobs, a dummy for receipt of formal training in the previous job and years of previous unemployment between the two previous jobs. Of course, we also introduce a dummy variable which is equal to one when the worker is a woman and to zero otherwise. The results are in column (1) of Table 3.

\section{Insert Table 3 here}

We find surprisingly a somewhat low value for the gender wage gap in Morocco. At the mean of the distribution, the residual wage gap is equal to $0.12 \log$ points once controlling for observable characteristics. Such a value is rather similar to that of many developed country. Recalling that the overall wage gap was around $0.24 \log$ points, this means that differences in labour market experience and education only account for a $0.12 \mathrm{log}$ point difference between male and female employees. Two explanations may come to mind. The first one is that the rather modest educational gap probably plays a role. The second one is undoubtedly the design of the 
survey, as we only have data on formal establishments with at least 10 employees in the manufacturing sector. Informal workers and individuals with very low wages are not observed ${ }^{12}$.

As we have matched employer-employee data, we can pick up the role of unobserved firm heterogeneity by including firm-specific dummies. We then estimate a fixed effects regression, whose results are in column 1 of Table 4. Several comments are in order. First, we still observe a negative and significant impact at the 1 percent level of the female dummy variable. Second, we find that inclusion of fixed effects has a limited impact on the magnitude of the gender wage gap. Indeed, the residual wage gap is equal to 13.6 percent, which is a little bit higher than the gap of 12 percent achieved with the standard OLS framework. Third, we assess the relevance of the fixed effect specification by comparing estimates from the random effects and the fixed effects models. We find a value of 34.65 for the Hausman statistics (with 11 degrees of freedom) that is significant at the 1 percent level, meaning that it matters to account for firm specific effects.

\section{Insert Table 4 bere}

In column 2 of Table 4, we estimate a linear model through OLS and add to the list of explanatory variables the set of firm factors obtained with the principal component analysis. The idea is that these firm factors should also control for heterogeneity at the firm level. Our findings suggest that this strategy is reliable, as our estimates with firm factors are very similar to those obtained with the fixed effects formulation. The mean gender wage gap evidenced with the augmented linear model is equal to 13.4 percent instead of 13.6 percent with the fixed effects model, and still significant at the 1 percent level. In what follows, we then rely on the firm factors strategy to account for firm specific effects in the quantile regressions.

\section{2/ Pooled quantile regressions}

We now estimate quantile regressions in order to know whether the magnitude of the gender earnings gap remains constant along the earnings distribution. Quantile regressions focus on specific parts of the conditional distribution of the dependent variable and provide estimates of the effect of gender, education or experience on log earnings at the bottom, at the median, and at the top of the log earnings distribution ${ }^{13}$. Let us briefly describe the underlying specification. We denote by $w_{i j}$ the log earnings of individual $i$ working in firm $j$ and $x_{i j}$ a vector of explanatory variables excluding gender. Let $f_{i j}$ be a dummy variable which is equal to one when

\footnotetext{
12 The problem is then that the data are restricted to workers employed in industries of the manufacturing sector, but it is common to rely on such data given the difficulties in measuring earnings for other segments of the labour market.

${ }^{13}$ The quantile regression method provides robust estimates, particularly for misspecification errors related to non-
} 
the employee is a woman (zero otherwise). We estimate the following regression:

$$
q_{\theta}\left(w_{i j} \mid x_{i j}\right)=x_{i j}{ }^{\prime} \beta(\theta)+f_{i j} \gamma(\theta)
$$

where $q_{\theta}\left(w_{i j} \mid x_{i j}\right)$ is the $\theta^{\text {th }}$ conditional quantile of $w_{i j}$. In a quantile regression, the distribution of the error term is left unspecified (Koenker and Bassett, 1978). The set of coefficients $\beta(\theta)$ provides the estimated rates of return to the different covariates (gender being excluded) at the $\boldsymbol{\theta}^{\text {th }}$ quantile of the log earnings distribution, while the coefficient $\gamma(\boldsymbol{\theta})$ measures the intercept shift due to gender differences.

When turning to the data, we begin by estimating the magnitude of the gender earnings gap on the whole sample, which includes both male and female employees. By pooling the data, we suppose that the returns to the labour market characteristics are the same at various quantiles for men and women. As this assumption does not necessarily hold, we will relax it latter on. With the pooled sample, the gender dummy in the quantile regressions may be interpreted as the effect of gender on log earnings at the various percentiles once one controls for any differences in observed labour market characteristics between genders. We first estimate the regressions with individual characteristics and neglect the potential role of firm heterogeneity. The corresponding estimates are in Table 3.

Let us focus on the gender dummy variable. Recalling that the mean wage gap is about 12 percent, we find that the gender wag gap is much lower at the bottom of the earnings distribution. Conditional on the set of explanatory variables, we find that the gap goes from about 6.5 percent at the bottom of the earnings distribution to about 15 percent at the top of this distribution $\left(95^{\text {th }}\right.$ percentile). Interestingly, it is equal to 8 percent at the $50^{\text {th }}$ percentile and the mean estimated gap is nearly similar to the gap estimated at the $3^{\text {rd }}$ quartile. Clearly, this increasing profile points to the existence of a glass ceiling effect which in Morocco works against women receiving higher wages.

We have also performed the same quantile regressions with inclusion of the firm factors. Indeed, it may be that the gender wage gap arises as a result of the sorting of workers across firms that pay different wages. If this is true, one would expect the coefficient on the gender dummy to be much lower (and virtually non-existent) once firm factor effects are controlled for. As shown in Table 4, estimates with firm factors lead to a slight increase in the value of the gender dummy coefficient. However, the gender gap widens in the upper tail of the conditional earnings distribution. For instance, the gender gap with firm factors at the median of the sample 
is equal to 8.9 percent instead of 8 percent with no firm factors, but the difference between both values is much larger at the $95^{\text {th }}$ percentile of the earnings distribution. The gender coefficient is equal to 18.3 percent with firm factors instead of 15.5 percent with no firm factors. Hence, controlling for firm specific effects matters when estimating the magnitude of the glass ceiling phenomenon $^{14}$.

Two additional comments are in order. First, with respect to the unadjusted gender gap described in Figure 1, these estimates show that part of the earnings gap stems from gender differences in observed characteristics. Second, albeit the differences along the earnings distribution remain rather small compared to those found for other countries (in particularly Sweden), it matters to stress that the differences across quantiles remain significant. In Figure 2, we plot the values for the gender wage gap once controlling for observable characteristics and firm factors and add the associated confidence intervals. We observe that the confidence intervals respectively at the bottom and at the top of the distribution are disjoint ${ }^{15}$.

\section{Insert Figure 2 bere}

So far, we did not account for occupation status in the various earnings regressions. It could be argued that the female dummy variable partially picks up these occupational effects, thereby leading to an over-estimated gender effect. A problem is that occupational assignment may be itself an outcome of employer practices rather than an outcome of differences in productivity or individual choice (Albrecht et alii, 2003) ${ }^{16}$. We thus reestimate the various quantile regressions and include four dummies for occupational status. The results, not reported, indicate that the magnitude of the gender wage gap is reduced at the upper part of the distribution.

Without firm factors, the median wage gap is now equal to 6.3 percent instead of 8 percent. The difference between both measures is still around 2 points of percentage at the $75^{\text {th }}$ percentile (12.6 percent instead of 14.7 percent), while it is much higher at the $95^{\text {th }}$ percentile (10 percent instead of 15.5 percent). Results are very similar once we account for firm heterogeneity ${ }^{17}$. However, in both case (either with or without firm factors), we still observe an increasing gender earnings gap along the earnings distribution. With firm factors, the gap goes from 6.4 percent at the $1^{\text {st }}$ quartile to 7.9 percent at the $3^{\text {rd }}$ quartile, the maximum gap of 12.4 percent being reached at the $95^{\text {th }}$ percentile. The data confirm the presence of a glass ceiling effect in Moroccan manufacturing firms, albeit it seems difficult to know whether differences in

\footnotetext{
${ }^{14}$ Earnings equations with firm factors have also a better fit than the standard Mincerian earnings functions.

15 The same result holds when the different quantile regressions do not include the set of firm factors.

${ }_{16}$ This would occur for instance if employers differentiate between men and women through their tendency to hire into certain occupations.

${ }^{17}$ For instance, at the $95^{\text {th }}$ percentile, the gender wage gap is equal to 18.3 percent with no control for occupation
} 
occupations are related to a form of gender discrimination.

\section{3/Gender-differentiated returns to individual characteristics}

Under the assumption that the returns to individual characteristics are the same at various quantiles for men and women, we find a convex profile for years of education as evidenced by Söderbom et alii (2004) in Kenyan and Tanzanian manufacturing firms. The returns to each additional year of education are much higher in the upper part of the earnings distribution, especially above the $3^{\text {rd }}$ quartile. A concave profile is found for potential experience, the marginal benefit of each additional year of experience being larger for higher levels of conditional earnings. This is consistent with findings from Portugal, where all aspects of human capital are more valued specifically for high paying jobs (Machado and Mata, 2001). While the impact of tenure in the current firm does not really vary along the earnings distribution, earnings increase with the number of preceding jobs, especially in the upper part of the distribution and are also higher when the worker has received formal training in the previous job.

A difficulty however is that the pooling assumption does not really seem realistic. In Morocco, the objective of an equal treatment of men and women in the labour market is far from being achieved. We test the relevance of this assumption by adding into the previous earnings functions the same covariates crossed with the gender dummy. If the coefficients associated with the crossed variables are significantly different from zero, then the assumption of equal returns to individual characteristics for male and female employees has to be rejected. When computing Wald tests to assess the joint significativeness of the crossed variables, the hypothesis of joint nullity is rejected at the 1 percent level for the various quantile regressions ${ }^{18}$.

We then estimate specific earnings regressions respectively for men and for women. We rely on quantile regressions and include firm factors in order to pick up unobserved heterogeneity at the firm level. These gender-specific regressions are reported in Table 5. We note that the returns to education are slightly higher for men than for women, and this occurs throughout the whole earnings distribution. Each additional year of experience in the current firm has a much higher return for men than for women. For females, a rise in the number of previous jobs before the current one increases by about 3 percent the level of income, at least till the $50^{\text {th }}$ percentile. Finally, the rewards of formal training are higher for men in the lower part of the conditional income distribution, but slightly higher for women above the $90^{\text {th }}$ percentile.

and about 12.4 percent with inclusion of dummies for occupations.

18 At the median value of the earnings distribution, gender differences in the returns to observable characteristics mainly stem from education and formal training in the previous job. In the lower part of the distribution, differences between men and women are mainly linked to education, tenure in the current firm and number of preceding jobs. 


\section{5/ Additional findings}

\section{1/ Insights from decomposition analyses}

We turn to a decomposition analysis of the gender pay gap. We seek to decompose the difference between the male and female log earnings distributions into two components. The first one is due to differences in labour market characteristics between male and female employees. The second is related to differences in the returns that men and women receive for their observable characteristics. We proceed in the following way.

First, we implement the classical Oaxaca-Blinder decomposition, whose aim is to identify the sources of differences between the means of the male and female distribution (Oaxaca and Ramson, 1994). Formally, let us denote by $\beta^{m}$ and $\beta^{f}$ the men and women's returns to labour market characteristics, respectively $x^{m}$ and $x^{f}$. The decomposition of the difference between the male and female earnings densities may be expressed as:

$$
x^{m} \beta^{m}-x^{f} \beta^{f}=x^{m}\left(\beta^{m}-\beta^{f}\right)+\left(x^{m}-x^{f}\right) \beta^{f}
$$

meaning that the counterfactual distribution is defined as the one that would arise if women were endowed on the basis of men's labour market characteristics and were paid like women ${ }^{19}$. In (2), the first term on the right hand side indicates the magnitude of the gap at the mean of the sample which is due to differences in the rewards to these characteristics. The second term indicates the magnitude of the mean gap which is due to dissimilarities in labour market characteristics.

Following the technique recently discussed in Machado and Mata (2005), we have also implemented the above decomposition at each quantile of the earnings distribution. The decomposition of the difference between the male and female earnings densities is now:

$$
x^{m} \beta^{m}(\theta)-x^{f} \beta^{f}(\theta)=x^{m}\left(\beta^{m}(\theta)-\beta^{f}(\theta)\right)+\left(x^{m}-x^{f}\right) \beta^{f}(\theta)
$$

with $\beta^{m}(\theta)$ and $\beta^{f}(\theta)$ the returns to the different covariates at the $\theta^{\text {th }}$ quantile of the $\log$ earnings distribution. To construct the counterfactual density, we rely on the three following steps. First, we draw a random sample of 150 numbers from a standard uniform distribution. Then, using these different numbers denoted by $\theta_{j}$, with $j=1, \ldots, 150$, we estimate the quantile regressions coefficient vectors $\beta^{f}\left(\theta_{j}\right)$ for the various $j$ using the female subsample. Finally, we take a draw $j$ times with replacement from the male subsample and generate the predicted

\footnotetext{
19 Note that a second counterfactual density may be constructed. It would be the density that would arise if men were endowed on the basis of women's labour market characteristics, but were paid like men.
} 
earnings $x^{m} \beta^{f}\left(\theta_{j}\right)$. This counterfactual female log wage density indicates what men would have earned if they were paid like women ${ }^{20}$.

Let us first discuss the decomposition at the mean. As shown in Table 6, the gender gap is equal to 24.4 percent at the mean of the sample. Around one half of the gap is due to differences between men and women in the characteristics introduced into the regressions (13.3 percent). The other half (11.1 percent) stems from gender differences in the rewards to these covariates. Another finding is that accounting for firm factors has little impact on the mean decomposition. The gender gap is virtually the same and we observe only a very small decrease in the weight of the component due to differences in observable characteristics.

\section{Insert Table 6 bere}

We now consider the quantile decomposition performed respectively at the $10^{\text {th }}, 25^{\text {th }}, 50^{\text {th }}$, $75^{\text {th }}$ and $90^{\text {th }}$ percentiles of the distribution. Using women's returns and assuming that these females have the male distribution of labour market characteristics, the counterfactual gender earnings gap is much lower than the observed pay gap. At the median of the distribution, the total gender gap is around 23.2 percent. This gap depends more heavily on differences in coefficients (13.7 percent) than in differences in characteristics ( 9.5 percent). While the weight of both components is almost identical in the lower part of the distribution, we observe conversely that differences in characteristics are relatively more important in the upper part of the earnings distribution.

The fact that gender differences in individual characteristics explain the larger gap observed at the top of the distribution is at odd with empirical findings in developed countries. For instance, in Sweden, the gender pay gap mainly stems from differences in the rewards of individual variables (Albrecht et alii, 2003). Another finding is that introducing the firm factors in the decomposition increases the weight of the component measuring differences in coefficients at the top of the distribution $\left(90^{\text {th }}\right.$ percentile). Conversely, it has little effect at the bottom of the distribution. Within firms where women and men have identical labour market characteristics, females are less rewarded for their observed endowments than males when they reach top positions.

\section{2/W age growth and the gender gap}

All the previous regressions that show an increasing gender wage gap along the earnings distribution are based on the earnings level in 1999. Since the data also include information on the

\footnotetext{
${ }^{20}$ In order to get standard errors for the different terms of the quantile decomposition, we replicate the whole
} 
level of earnings in 1998, we now investigate the impact of gender on the log wage growth. Although we have a one year period, the focus on the log wage growth allows us to control for individual heterogeneity. Suppose that there exists an unobserved worker fixed effect $\phi_{i}$, constant over time. We can express the earnings levels for the two periods as $w_{i j}^{98}=x_{i j}^{981} \beta^{98}+\phi_{i}+\varepsilon_{i j}^{98}$ and $w_{i j}^{99}=x_{i j}^{99} \beta^{99}+\phi_{i}+\varepsilon_{i j}^{99}$. Then, relying on a first-difference approach, we get:

$$
w_{i j}^{99}-w_{i j}^{98}=x_{i j}^{99 !} \beta^{99}-x_{i j}^{981} \beta^{98}+\varepsilon_{i j}^{99}-\varepsilon_{i j}^{98}
$$

so that the individual fixed component is removed. A difficulty with the difference approach in this context is that many covariates introduced into the earnings equation are fixed over time, so that they can no longer be included as covariates. Another problem stems from the fact that for many workers, there is absolutely no change in earnings between 1998 and 1999. A quantile regression method would clearly not make sense in this context.

We estimate instead linear regression models by gender as in Manning and Swaffield (2005). The idea is to compare the predicted wage growth by gender, depending on a set of covariates. However, unlike these authors who only focus on the mean of the log wage growth, we also wonder whether there exist any gender differences in the earnings growth depending on the workers' relative position across the earnings distribution. For that purpose, we choose to perform our estimations conditional on the initial position in the distribution. Specifically, we compute the predicted log earnings growth for four subsamples, which are given by the belonging to the various quartiles of earnings in $1998^{21}$.

We first calculate the means of the log earnings growth for men and women, with no explanatory variables. As shown in Table 7, there exist some slight differences by gender. Among those who were in the lowest quartile in 1998, the mean rise in income is about 1 point of percentage higher for women. A different pattern is found for the three remaining quartiles since the wage growth is more important for men, albeit the differences are not significant (about 0.30 percentage point). Then, we introduce potential experience alone in a quadratic form in the regressions. For the lowest quartile, we still find a higher growth for women, but the magnitude of the growth gap is now reduced. Conversely, for the third and fourth quartiles of incomes, we obtain a much higher positive value for the gender difference in wage growth.

\section{Insert Table 7 bere}

procedure exactly 50 times.

${ }^{21}$ Note that we loose 8 percent and 11 percent of the sub-samples of men and women respectively due to missing data on the level of earnings in 1998. Except a lower average years of tenure in the current firm (1.3 instead of 8 years), these individuals have no other noticeable differentiated human capital characteristics as compared to the individuals for whom earnings in 1998 are available. 
This suggests that the glass ceiling effect may be stronger at older ages in manufacturing firms in Morocco, as high wage men benefit from higher increase in earnings than women. However, a focus on mean values for wage growth would lead to misleading conclusions, since a comparison of the male and female mean wage growth leads to an insignificant gap of 0.03 percent. Finally, we estimate two additional models with more control variables and get the following results. First, we get more acute gender differences. In the lowest quartile, women benefit from more generous increase in income, while the mean growth is about 2 percent higher for men in the highest quartile. Second, differences in log earnings growth are not really affected by the inclusion of occupation status, the male excess gap ranging from -1.2 percent for the first quartile till +2.1 percent for the upper one.

\section{3/ The within-firm gender earnings gap}

We finally investigate the factors that influence firms to pay different premia for men and women. We restrict our attention to the mean of the earnings distribution and focus on the difference between the male and female firm fixed effects stemming from the regressions:

$$
\begin{aligned}
& w_{i j}^{m}=x_{i j}^{m \prime} \beta^{m}+\phi_{j}^{m}+\varepsilon_{i j}^{m} \\
& w_{i j}^{f}=x_{i j}^{f} \beta^{f}+\phi_{j}^{f}+\varepsilon_{i j}^{f}
\end{aligned}
$$

Both fixed effect models are estimated on the sample of firms which have at least two male and two female observations ${ }^{22}$. These regressions are estimated on 2,999 male workers and 2,487 female workers and we retrieve for a given firm the fixed effects respectively for men and women. A F-test indicates that the two sets of fixed effects $\hat{\phi}_{j}^{m}$ and $\hat{\phi}_{j}^{f}$ are significantly different. Then, we follow Meng (2004) and compute the difference $\hat{\phi}_{j}^{m}-\hat{\phi}_{j}^{f}$ that may be seen as an estimate of the within-firm gender earnings gap.

To explain this within-firm, we introduce explanatory variables related to observable firm characteristics. The difference in fixed effects is estimated using simple OLS regressions, and the corresponding estimates are shown in Table 8. We perform two sets of estimates, as we present the determinants of the within-firm gender earnings gap obtained alternatively with and without dummies for individual occupation in the first step earnings regressions ${ }^{23}$. Explaining the within-

\footnotetext{
22 This reduces by less than one third our initial sample of firms. For comparisons, summary statistics of the firms' characteristics for the restricted and unrestricted samples of firms are reported in Table 1 . Let us note that the sample restriction hardly changed anything with regard to the sectoral distribution and other firm characteristics. As a matter of fact, the only noticeable changes between the two samples are quite expected and concern the share of female employees and the proportion of garment firms in the sample (which are highly female intensive in Morocco). ${ }_{23}$ Again, it is debatable whether job characteristics or occupation should be taken into account. If employers
} 
firm gender earnings gap is quite difficult, as the $R^{2}$ is around 10 percent. Meng and Meurs (2004) find that less than 4 percent of the variation of this within-firm gender gap is explained by observable firm characteristics in France and about 7 percent in Australia.

\section{Insert Table 8 bere}

A few sectoral dummies are statistically significant in the regressions, at least with controls for the effect of occupation on earnings. Compared to garment companies, the withinfirm gender gap is significantly higher in the electrical and textile sectors. Also, the firm gender pay gap is an increasing function of the firm size, which may be due to more opportunities for large firms to discriminate between their male and female workers. Moreover, the data indicate that firms which are mainly foreign-owned operate with more discrimination with respect to female workers than other firms. These results may be explained by the fact that, under strong product market competition, firms may not be able to afford to discriminate and will therefore try to reduce the level of discrimination (Arrow, 1973). By contrast, firms with more market power, such as foreign-owned or large firms in our case, may be more likely to discriminate against women (Hellerstein et alii, 2002) ${ }^{24}$.

Another argument that explains why some firms may be more likely to discriminate than others concerns the availability of information on workers' productivity. The dummy for a high share of managers in the firms exerts a negative impact on the within-firm gender gap. This can be explained by the fact that firms with high supervision rates have a priori more information on workers' productivity. Observing individual productivity may reduce uncertainty and therefore the tendency to discriminate. In the same vein, highly labour intensive firms, where productivity can less easily be observed, discriminate more than other firms. Moreover, the share of days lost due to strike and the share of sales lost due to theft have significant and positive effects on the size of the within-firm gender pay gap. This may also reveal that discrimination practices arise in firms where there is greater uncertainty on workers' behaviour ${ }^{25}$.

Finally, another interesting result concerns the firms' promotion policy. Firms with a high share of promoted executives the last year considered are characterised by higher within-firm gender gap. This may be a sign that promotion is essentially reserved to males in this type of

\footnotetext{
differentiate between men and women through their to hire into certain occupations, then occupational assignment is an outcome of employer practices rather than an outcome of individual choice or productivity differences (Altonji and Blank, 1999). Conversely, it could be argued that analyses omitting occupation may underestimate the importance of background and choice-based characteristics on labour market outcomes.

${ }^{24}$ Note that the variable indicating the firm's market share is significant in column 2 only (at the 10 percent level), but exerts a positive effect on the within-firm gender gap indeed.

${ }^{25}$ However, let us note that the share of days lost due to absenteeism plays significantly in opposite sense, which recommends us to interpret these proxies of uncertainty with some cautious.
} 
firms. These gender-differentiated promotions are one of the sources of the glass ceiling effect and are fully consistent with our previous results on wage growth.

\section{6/ Conclusion}

In this paper, we investigate the relevance of the glass ceiling hypothesis in Morocco, according to which in developed countries, there exist larger gender wage gaps at the upper tail of the wage distribution. Using a matched worker-firm data set of more than 8,000 employees and 850 employers, we estimate quantile regressions and perform counterfactual gender earnings gap decompositions at different quantiles while taking account of firms' effects on earnings differentials. We then propose estimates of the within-firm earnings growth by gender as well as estimates of the determinants of the within-firm gender earnings gap using our information on the firms' characteristics.

Our estimates lead to the following results. As in many developed countries, there exists a glass ceiling effect in manufacturing firms of Morocco, the earnings gap being much higher at the top of the distribution than at the bottom. According to the results of the counterfactual density without firm heterogeneity controls, gender differences in labour market characteristics mostly explain the larger gap observed at the top of the distribution. This result is at odd with empirical findings in developed countries, in particular those in Sweden by Albrecht et alii (2003), where the bulk of the gender pay gap is mainly due to differences in the returns to individual characteristics (especially in the upper part of the distribution).

The previous authors having evidenced the presence of the glass ceiling phenomenon did not make use of matched worker-firm data. Moreover, our study is the first one of this kind being applied on a developing country. Our findings suggest that it matters to account for firms' characteristics. Indeed, controlling for firm-specific effects increases the value and significance of the gender dummy coefficient along the earnings distribution. Not only the gender gap is not reduced when capturing the firm effects on earnings differentials, but it widens significantly in the upper tail of the earnings distribution, thereby reinforcing the presence of the glass ceiling phenomenon.

Then, the results of the counterfactual decompositions with firm effects emphasise that, within firms where women and men have identical labour market characteristics, females are less rewarded for their observed endowments than males are and this is all the more true when they reach top positions. Hence, empirical results on the log gender pay gap which would not control for the firm effects may understate the earnings differences between men and women. In that sense, our results evidenced for a developing country like Morocco are different from those 
observed in European countries where the gender wage gap is often observed to be overstated when controls for firm heterogeneity are missing.

Our study also goes one step further by comparing the wage growth by gender along the earnings distribution. Our results suggest that the glass ceiling effect might be reinforced over time in Morocco, as high wage male workers benefit from higher increase in earnings than women do. Finally, thanks to the rich firm-level information, we are able to disentangle the various forces at work in the formation of the within-firm gender earnings gap. Among other results, we find that observing individual productivity and getting information on workers is likely to reduce employers' uncertainty, which in turn leaves fewer places to gender earnings discrimination.

From a policy viewpoint, the next step is to understand the causes of the glass ceiling. If the gender pay gap is linked to the work environment faced by women, this implies that all the policies which may influence the interaction between work and family matters. For instance, policies providing strong incentive to participate in the labour force for women, like financial benefits after birth or subsidized access to day care, may discourage a strong career commitment from parents. This would be taken into account by employers, who would expect a much lower career commitment from female employees. At the same time, it may be very difficult for career oriented women with low or medium wage to hire household help or to pay for formal child care, leading to a lower involvement in their jobs.

In developing countries, the glass ceiling effect is more likely to depend on the different educational choices of men and women since family policies are often inexistent there or insufficiently implemented. In Morocco for instance, managers in manufacturing firms are most often recruited from a limited number of educational backgrounds, in particular technical fields such as engineering or business administration. The difficulty is that women most often lack strong presence in these fields. Promoting access to such educational paths for women, with for instance a minimal number of girls into such educational establishments, could in turn help dismantle part of the glass ceiling effect. 


\section{References}

Abowd J.M., Kramarz F. (1999), "The analysis of labor markets using matched employeremployee data", in Ashenfelter O. and Card D. (eds), Handbook of Labor Economics, vol. 3B, Elsevier, North-Holland, pp. 2629-2710.

Agenor P.-R., El Aynaoui K. (2003), "Labor market policies and unemployment in Morocco", World Bank Policy Research Working Paper 3091, Washington: The World Bank.

Albrecht J., Björklund A., Vroman S. (2003), "Is there a glass ceiling in Sweden?”, Journal of Labor Economics, vol. 21, pp. 145-177.

Albrecht J., van Vuuren A., Vroman S. (2006), "Counterfactual distributions with sample selection adjustments: Econometric theory and an application to the Netherlands", mimeo, University of Georgetown.

Altonji J.G., Blank R.M. (1999), "Race and gender in the labor market", in Ashenfelter O.C. and Card D. (eds), Handbook of Labor Economics, vol. 3C, Elsevier, chapter 48, pp. 3143-3258.

Arrow K.J. (1973), "The theory of discrimination", in Ashenfelter O.C. and Rees A. (eds), Discrimination in Labour Markets, Princeton Uni. Press, Princeton, NJ, pp. 3-33.

Arulampalam W., Booth A.L., Bryan M.L. (2004), "Is there a glass ceiling over Europe? Exploring the gender pay gap across the wages distribution", IZA Discussion Paper, $\mathrm{n}^{\circ} 1373$.

Appleton S., Hoddinott J., Krishnan P. (1999), "The gender wage gap in three African countries”, Economic Development and Cultural Change, vol. 47, n² 2 pp. 289-312.

Benhayoun G., Bazen S., Lazzeri Y., Moustier E., Guillaumet P. (2001), "Le salaire minimum au Maroc", unpublished, Ministère de l'Emploi, de la Formation Professionnelle, du Développement Social et de la Solidarité, July.

Bonjour D., Gerfin M. (2001), “The unequal distribution of unequal pay. An empirical analysis of the gender wage gap in Switzerland", Empirical Economics, vol. 26, pp. 407-427.

Buchinsky M. (1998), "Recent advances in quantile regression models: A practical guideline for empirical research", The Journal of Human Resources, vol. 33, n¹, pp. 88-126.

Clerides S.K., Lach S., Tybout J.R. (1998), "Is learning by exporting important? Micro-dynamic evidence from Columbia, Mexico, and Morocco", The Quarterly Journal of Economics, 113(3), pp. 903-947.

Cling J.-P., Razafindrakoto M., Roubaud F. (2003), New International Poverty Reduction Strategies, London/New York: Routledge.

Datta Gupta N., Oaxaca R.L., Smith N. (2006), "Swimming upstream, floating downstream: Comparing women's relative wage positions in the US and Denmark", Industrial and Labor Relations Review, vol. 59, n² 2, pp. 243-266.

De la Rica S., Dolado J.J., Llorens S. (2005), "Ceiling and floors: Gender wage gaps by education in Spain”, IZA Discussion Paper, n 1483.

Del Rio C., Gradin C., Canto O. (2005), “The measurement of gender wage discrimination: The distributional approach revisited', Mimeographed, Universidad de Vigo.

Fitzenberger B., Wunderlich G. (2002), "Gender wage differences in West Germany: A cohort analysis", German Economic Review, vol. 3, pp. 379-414.

Fafchamps M., Söderbom M., Benhassine N. (2006), "Job sorting in African labor markets", Mimeographed, University of Oxford, January. 
Gardeazabal J., Ugidos A. (2005), "Gender wage discrimination at quantiles", Journal of Population Economics, vol. 18, pp. 165-179.

Hellerstein J., Neumark D., Troske K. (2002), "Market forces and sex discrimination", Journal of Human Resources, vol. 37(2), pp. 353-380.

Koenker R., Bassett G. (1978), "Regression quantiles”, Econometrica, vol. 46, pp. 33-50.

Kuepie M., Nordman C., Roubaud F. (2006), "Education and labour market outcomes in SubSaharan West Africa", DIAL Working Paper, DT/2006/16, DIAL, Paris.

Jellal M., Nordman C., Wolff F.C. (2007), "Evidence on the glass ceiling in France using matched worker-firm data", Applied Economics, forthcoming.

Lane J., Hakim G., Miranda J. (1999), "Labor market analysis and public policy: the case of Morocco", The World Bank Economic Review, vol. 13(3), pp. 561-578.

Machado J.A., Mata J. (2001), "Earning functions in Portugal 1982-1984: Evidence from quantile regressions”, Empirical Economics, vol. 26, pp. 115-134.

Machado J.A., Mata J. (2005), "Counterfactual decomposition of changes in wage distributions using quantile regression", Journal of Applied Econometrics, vol. 20(4), pp. 445-465.

Maddala G.S. (1977), Econometrics, New York: McGraw-Hill.

Mairesse J., Greenan N. (1999), "Using employee level data in a firm level econometric Study", NBER Working Paper, \#7028.

Manning A., Swaffield J. (2005), "The gender gap in early-career wage growth", Centre for Economic Performance (CEP) Discussion Paper, n ${ }^{\circ} 70$, London.

Meng X., (2004), "Gender earnings gap: the role of firm specific effects", Labour Economics, vol. 11, pp. 555-573.

Meng X., Meurs D. (2004), "The gender earnings gap: Effects of institutions and firms. A comparative study of French and Australian private firms", Oxford Economic Papers, vol. 56, pp. 189-208.

Montenegro C. (2001), "Wage distribution in Chile: Does gender matter? A quantile regression approach”, World Bank Policy Research Working Paper 20, Washington: The World Bank.

Muller C., Nordman C. (2004), "Which human capital matters for rich and poor's wages? Evidence from matched worker-firm data from Tunisia", DIAL Working Paper, DT/2004/09, DIAL, Paris. CREDIT Research Paper, 04/08, University of Nottingham.

Mwabu G., Schultz T. P. (1996), "Education returns across quantiles of the wage function", American Economic Review, vol. 86, pp. 335-39.

Nordman C., Roubaud F. (2005), "Reassessing the gender wage gap: Does labour force attachment really matter? Evidence from matched labour force and biographical surveys in Madagascar", DIAL Working Paper, DT/2005/06, Paris.

Oaxaca R., Ramson M. (1994), "On discrimination and the decomposition of wage differentials", Journal of Econometrics, vol. 61, pp. 5-21.

Said M. (2003), "The distribution of gender and public pay sector premia: Evidence from the Egyptian organized sector", School of Oriental and African Studies Working paper, University of London, $\mathrm{n}^{\circ} 132$.

Söderbom M., Teal F., Wambugu A., Kahyarara G. (2004), "Dynamics of returns to education in Kenyan and Tanzanian manufacturing", CSAE Working Paper Series, 2003-17, University of Oxford. 
World Bank (1994), Royaume du Maroc vers le 21 siècle : renforcement du secteur privé au Maroc, Report \#11894-MOR, Washington.

World Bank (2001), Kingdom of Morocco: Poverty Update, Vol. I: Main Report, Report No. 215-MOR, March 30, Washington.

World Bank (2002), "Moroccan manufacturing sector at the turn of the century", FACSMorocco, Joint project of the Ministère de l'Industrie, du Commerce, de l'Energie et des Mines du Maroc and The World Bank.

Weichselbaumer D., Winter-Ebmer R. (2005), “A meta-analysis of the international gender wage gap”, Journal of Economic Surveys, vol. 19(3), pp. 479-511. 
Figure 1. The log gender earnings gap in Morocco, with $95 \%$ confidence intervals

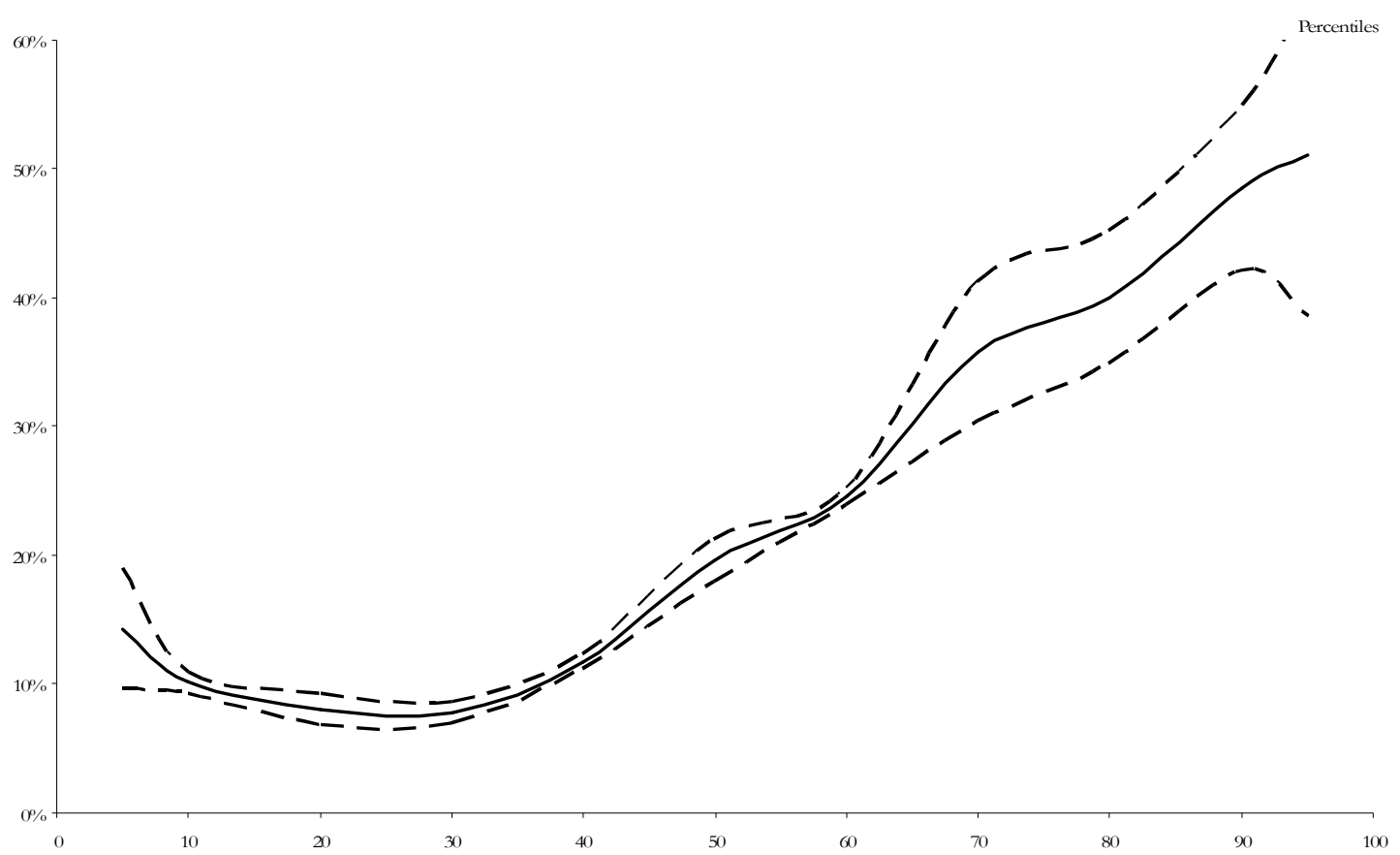

Source: FACS Morocco 2000

Figure 2. The predicted log gender earnings gap in Morocco, with $95 \%$ confidence intervals

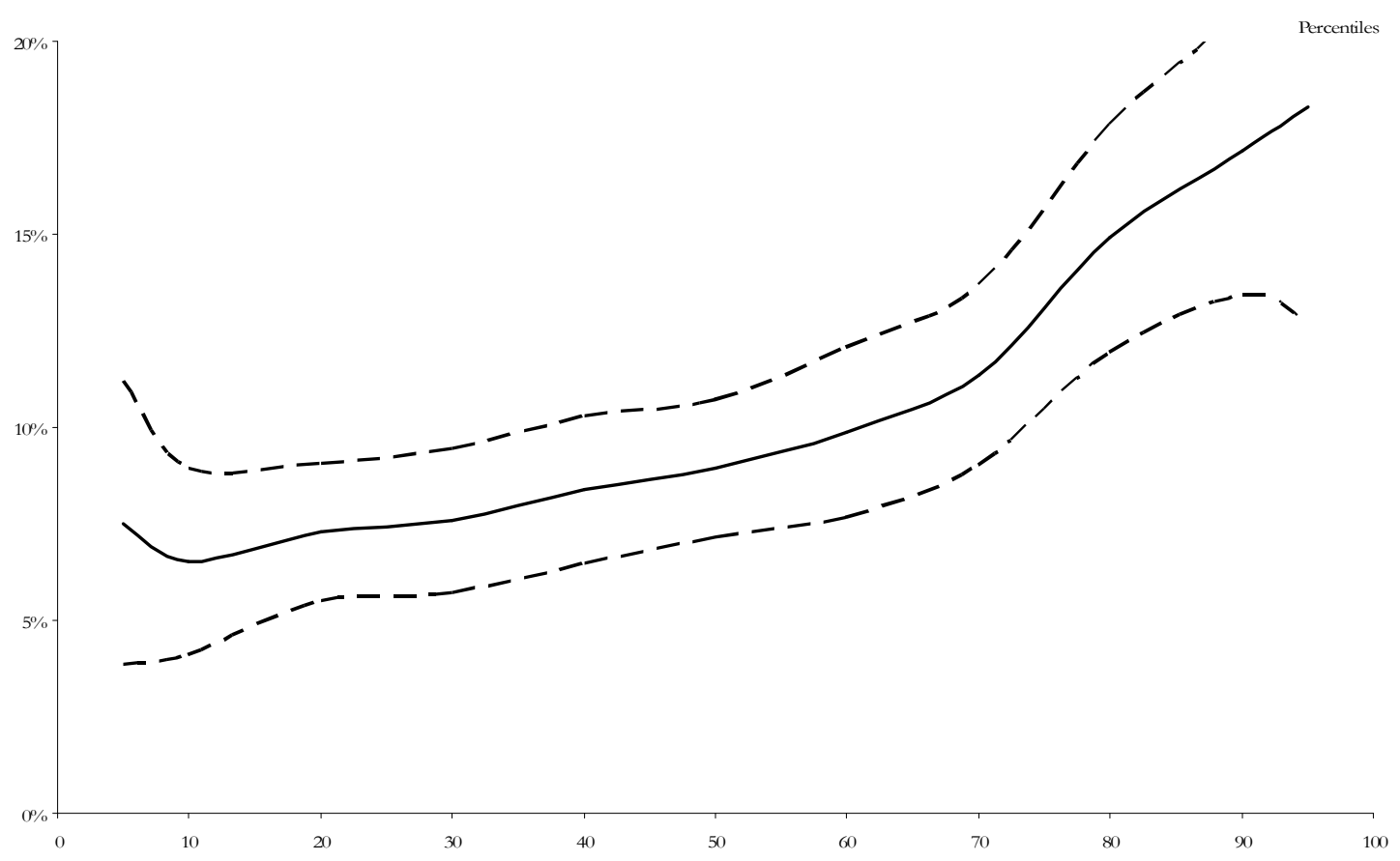

Source: FACS Morocco 2000 
Table 1. Descriptive statistics of the firm characteristics

\begin{tabular}{|c|c|c|c|c|}
\hline Variables & Mean & $\begin{array}{l}\text { Standard } \\
\text { deviation }\end{array}$ & Mean & $\begin{array}{l}\text { Standard } \\
\text { deviation }\end{array}$ \\
\hline & \multicolumn{2}{|c|}{ Unrestricted sample } & \multicolumn{2}{|c|}{ Restricted sample } \\
\hline $\begin{array}{l}\text { Dummies for sector of affiliation } \\
\text { Garment } \\
\text { Food } \\
\text { Textile } \\
\text { Leather } \\
\text { Electrical } \\
\text { Chemicals } \\
\text { Plastics }\end{array}$ & $\begin{array}{l}0.367 \\
0.097 \\
0.233 \\
0.080 \\
0.044 \\
0.090 \\
0.089\end{array}$ & & $\begin{array}{l}0.427 \\
0.088 \\
0.237 \\
0.064 \\
0.034 \\
0.078 \\
0.071\end{array}$ & \\
\hline \multicolumn{5}{|l|}{ Firm characteristics } \\
\hline Primarily exporting firms ( 1 if yes) & 0.565 & & 0.654 & \\
\hline Number of local competitors for the principal product & 161.154 & 402.503 & 176.649 & 406.667 \\
\hline Market share & 11.308 & 19.752 & 11.530 & 20.023 \\
\hline Share of female employees & 0.556 & 2.118 & 0.675 & 2.524 \\
\hline $\begin{array}{l}\text { Firm size }(1:<50 \text { employees, } 2: 50<\text { employees }<150,3: \\
\text { employees }>150)\end{array}$ & 1.800 & 0.776 & 1.883 & 0.787 \\
\hline Are the employees unionised? ( 1 if yes) & 0.132 & & 0.112 & \\
\hline Share of unionised employees & 0.097 & 0.271 & 0.084 & 0.253 \\
\hline Share of piece-rate pay for non-qualified employees & 0.006 & 0.066 & 0.001 & 0.017 \\
\hline Qualified employees being dominant occupation (1 if yes) & 0.320 & & 0.337 & \\
\hline $\begin{array}{l}\text { Share of managers higher than } 10 \% \text { of the total employees } \\
\text { (1 if yes) }\end{array}$ & 0.120 & & 0.100 & \\
\hline $\begin{array}{l}\text { Highly labour intensive firms in } 1998 \text { ( } 1 \text { if labour costs }> \\
75 \% \text { total costs) }\end{array}$ & 0.050 & & 0.053 & \\
\hline Firms with more than $75 \%$ foreign owned ( 1 if yes) & 0.041 & & 0.049 & \\
\hline Profitable firms ( 1 if yes) & 0.623 & & 0.632 & \\
\hline Share of days lost due to absenteeism & 0.024 & 0.056 & 0.024 & 0.057 \\
\hline Share of days lost due to strike & 0.002 & 0.024 & 0.002 & 0.028 \\
\hline Share of sales lost due to theft & 0.003 & 0.011 & 0.003 & 0.012 \\
\hline Share of executives promoted in 1999 & 0.014 & 0.119 & 0.005 & 0.040 \\
\hline Number of on-the-job day-trainees in 1999 & 124.8 & 1887.5 & 162.3 & 2264.3 \\
\hline Sales in 1999 (in Dirhams) & 23502 & 49761 & 26083 & 55168 \\
\hline Value of production in 1999 (in Dirhams) & 22196 & 45340 & 24628 & 49735 \\
\hline Number of observations & & & & \\
\hline
\end{tabular}

Source: FACS Morocco 2000

The unrestricted sample includes all the firms of the FACS (excluding four of them with missing values) while the restricted sample comprises firms which do not have at least two male and two female employees. 
Table 2. Descriptive statistics of the worker characteristics

\begin{tabular}{|c|c|c|c|}
\hline Variables & Male & Female & All \\
\hline \multicolumn{4}{|l|}{ Earnings } \\
\hline $\begin{array}{l}\text { Log monthly earnings }- \text { mean } \\
\text { Log monthly earnings }-5 \text { th percentile } \\
\text { Log monthly earnings }-10 \text { th percentile } \\
\text { Log monthly earnings }-25 \text { th percentile } \\
\text { Log monthly earnings }-50 \text { th percentile } \\
\text { Log monthly earnings }-75 \text { th percentile } \\
\text { Log monthly earnings }-90 \text { th percentile } \\
\text { Log monthly earnings }-95 \text { th percentile }\end{array}$ & $\begin{array}{l}7.96 \\
7.31 \\
7.41 \\
7.56 \\
7.80 \\
8.26 \\
8.78 \\
9.21\end{array}$ & $\begin{array}{l}7.72 \\
7.17 \\
7.31 \\
7.45 \\
7.60 \\
7.82 \\
8.29 \\
8.70\end{array}$ & $\begin{array}{l}7.87 \\
7.24 \\
7.38 \\
7.51 \\
7.69 \\
8.10 \\
8.63 \\
9.05\end{array}$ \\
\hline \multicolumn{4}{|l|}{ Other characteristics } \\
\hline Dummy for being female & 0 & 1 & 0.40 \\
\hline Dummy for managers & 0.06 & 0.02 & 0.04 \\
\hline Dummy for executives & 0.11 & 0.07 & 0.09 \\
\hline Dummy for skilled workers/technicians & 0.40 & 0.38 & 0.38 \\
\hline Dummy for unskilled production workers & 0.27 & 0.34 & 0.29 \\
\hline Dummy non-production employees & 0.15 & 0.18 & 0.16 \\
\hline Dummy for apprentices & 0.00 & 0.01 & 0.00 \\
\hline Number of children & 1.81 & 0.65 & 1.32 \\
\hline Years of completed schooling & 8.83 & 8.55 & 8.72 \\
\hline $\begin{array}{l}\text { Years of potential experience } \\
(\text { age }- \text { schooling }-6)\end{array}$ & 22.03 & 16.91 & 19.98 \\
\hline Years of tenure in the current firm & 8.12 & 5.98 & 7.26 \\
\hline Number of preceding jobs & 1.32 & 0.97 & 1.16 \\
\hline $\begin{array}{l}\text { Dummy for received formal training in the } \\
\text { previous job }\end{array}$ & 0.03 & 0.02 & 0.02 \\
\hline $\begin{array}{l}\text { Years of previous unemployment between } \\
\text { the two previous jobs }\end{array}$ & 0.18 & 0.17 & 0.17 \\
\hline Observations & 5015 & 3320 & 8335 \\
\hline
\end{tabular}

Source: FACS Morocco 2000 
Table 3. OLS and quantile regressions of the log monthly earnings

\begin{tabular}{|c|c|c|c|c|c|c|c|c|}
\hline \multirow[t]{2}{*}{ Variables } & \multirow[t]{2}{*}{ OLS } & \multicolumn{7}{|c|}{ Quantile regressions } \\
\hline & & 0.05 & 0.10 & 0.25 & 0.50 & 0.75 & 0.90 & 0.95 \\
\hline Constant & $\begin{array}{c}7.031^{* * *} \\
(235.01)\end{array}$ & $\begin{array}{l}6.932^{* * *} \\
(127.11)\end{array}$ & $\begin{array}{l}7.061^{* * *} \\
(190.17)\end{array}$ & $\begin{array}{l}7.108^{* * *} \\
(275.09)\end{array}$ & $\begin{array}{l}7.118^{* * *} \\
(263.94)\end{array}$ & $\begin{array}{l}7.169^{* * *} \\
(203.71)\end{array}$ & $\begin{array}{l}7.247^{* * *} \\
(117.41)\end{array}$ & $\begin{array}{c}7.271^{* * *} \\
(91.60)\end{array}$ \\
\hline Dummy for being female & $\begin{array}{c}-0.120^{* * *} \\
(10.67)\end{array}$ & $\begin{array}{c}-0.065^{* * *} \\
(3.28)\end{array}$ & $\begin{array}{c}-0.067^{* * *} \\
(4.96)\end{array}$ & $\begin{array}{c}-0.063^{* * *} \\
(6.40)\end{array}$ & $\begin{array}{c}-0.080^{* * *} \\
(7.84)\end{array}$ & $\begin{array}{c}-0.125^{* * *} \\
(10.05)\end{array}$ & $\begin{array}{c}-0.147^{* * *} \\
(6.87)\end{array}$ & $\begin{array}{c}-0.155^{* * *} \\
(5.63)\end{array}$ \\
\hline Number of children & $\begin{array}{l}0.005 \\
(1.16)\end{array}$ & $\begin{array}{c}-0.003 \\
(0.47)\end{array}$ & $\begin{array}{c}-0.003 \\
(0.65)\end{array}$ & $\begin{array}{l}0.004 \\
(1.19)\end{array}$ & $\begin{array}{c}0.008^{* *} \\
(2.17)\end{array}$ & $\begin{array}{c}0.011^{* *} \\
(2.51)\end{array}$ & $\begin{array}{c}0.017^{* *} \\
(2.36)\end{array}$ & $\begin{array}{l}0.003 \\
(0.39)\end{array}$ \\
\hline Years of completed schooling & $\begin{array}{c}-0.030^{* * *} \\
(8.44)\end{array}$ & $\begin{array}{c}-0.012^{*} \\
(1.78)\end{array}$ & $\begin{array}{c}-0.009^{* *} \\
(1.98)\end{array}$ & $\begin{array}{c}-0.016^{* * *} \\
(5.12)\end{array}$ & $\begin{array}{c}-0.031^{* * *} \\
(9.76)\end{array}$ & $\begin{array}{c}-0.037^{* * *} \\
(8.95)\end{array}$ & $\begin{array}{c}-0.043^{* * *} \\
(6.18)\end{array}$ & $\begin{array}{c}-0.030^{* * * *} \\
(3.33)\end{array}$ \\
\hline$(\text { Years of completed schooling })^{2} / 100$ & $\begin{array}{c}0.578^{* * *} \\
(28.13)\end{array}$ & $\begin{array}{c}0.219^{* * *} \\
(5.40)\end{array}$ & $\begin{array}{c}0.201^{* * *} \\
(7.93)\end{array}$ & $\begin{array}{c}0.302^{* * *} \\
(16.97)\end{array}$ & $\begin{array}{c}0.513^{* * *} \\
(27.67)\end{array}$ & $\begin{array}{c}0.699^{* * *} \\
(29.38)\end{array}$ & $\begin{array}{c}0.884^{* * *} \\
(21.08)\end{array}$ & $\begin{array}{c}0.878^{* * *} \\
(16.43)\end{array}$ \\
\hline Years of potential experience & $\begin{array}{c}0.031^{* * *} \\
(15.66)\end{array}$ & $\begin{array}{c}0.010^{* * *} \\
(2.78)\end{array}$ & $\begin{array}{c}0.011^{* * *} \\
(4.22)\end{array}$ & $\begin{array}{c}0.019^{* * *} \\
(11.16)\end{array}$ & $\begin{array}{c}0.028^{* * *} \\
(15.74)\end{array}$ & $\begin{array}{c}0.034^{* * *} \\
(14.81)\end{array}$ & $\begin{array}{c}0.037^{* * *} \\
(9.61)\end{array}$ & $\begin{array}{c}0.040^{* * *} \\
(8.17)\end{array}$ \\
\hline$(\text { Years of potential experience })^{2} / 100$ & $\begin{array}{c}-0.044^{* * *} \\
(11.80)\end{array}$ & $\begin{array}{c}-0.017^{* *} \\
(2.56)\end{array}$ & $\begin{array}{c}-0.015^{* * *} \\
(3.39)\end{array}$ & $\begin{array}{c}-0.031^{* * *} \\
(10.08)\end{array}$ & $\begin{array}{c}-0.047^{* * *} \\
(13.85)\end{array}$ & $\begin{array}{c}-0.048^{* * *} \\
(11.30)\end{array}$ & $\begin{array}{c}-0.047^{* * *} \\
(6.50)\end{array}$ & $\begin{array}{c}-0.043^{* * *} \\
(4.72)\end{array}$ \\
\hline Years of tenure in the current firm & $\begin{array}{c}0.015^{* * *} \\
(6.48)\end{array}$ & $\begin{array}{c}0.022^{* * *} \\
(5.46)\end{array}$ & $\begin{array}{c}0.015^{* * *} \\
(5.42)\end{array}$ & $\begin{array}{c}0.010^{* * *} \\
(5.16)\end{array}$ & $\begin{array}{c}0.010^{* * *} \\
(4.70)\end{array}$ & $\begin{array}{c}0.011^{* * *} \\
(4.23)\end{array}$ & $\begin{array}{c}0.016^{* * *} \\
(3.60)\end{array}$ & $\begin{array}{c}0.022^{* * *} \\
(3.88)\end{array}$ \\
\hline$(\text { Years of tenure in the current firm })^{2} / 100$ & $\begin{array}{l}0.001 \\
(0.14)\end{array}$ & $\begin{array}{c}-0.024^{* *} \\
(2.00)\end{array}$ & $\begin{array}{l}-0.013 \\
(1.46)\end{array}$ & $\begin{array}{l}0.003 \\
(0.39)\end{array}$ & $\begin{array}{c}0.023^{* * *} \\
(3.07)\end{array}$ & $\begin{array}{c}0.024^{* *} \\
(2.47)\end{array}$ & $\begin{array}{l}0.019 \\
(1.20)\end{array}$ & $\begin{array}{c}-0.004 \\
(0.19)\end{array}$ \\
\hline Number of preceding jobs & $\begin{array}{c}0.023^{* * *} \\
(6.97)\end{array}$ & $\begin{array}{l}0.013 \\
(1.59)\end{array}$ & $\begin{array}{c}0.013^{* *} \\
(2.46)\end{array}$ & $\begin{array}{c}0.017^{* * *} \\
(5.38)\end{array}$ & $\begin{array}{c}0.024^{* * *} \\
(8.14)\end{array}$ & $\begin{array}{c}0.027^{* * *} \\
(7.88)\end{array}$ & $\begin{array}{c}0.041^{* * *} \\
(7.12)\end{array}$ & $\begin{array}{c}0.036^{* * *} \\
(4.93)\end{array}$ \\
\hline Dummy for received formal training in the previous job & $\begin{array}{c}0.310^{* * *} \\
(8.65)\end{array}$ & $\begin{array}{c}0.135^{* *} \\
(2.22)\end{array}$ & $\begin{array}{c}0.117^{* * *} \\
(2.66)\end{array}$ & $\begin{array}{c}0.142^{* * *} \\
(4.57)\end{array}$ & $\begin{array}{c}0.392^{* * *} \\
(12.16)\end{array}$ & $\begin{array}{c}0.418^{* * *} \\
(10.52)\end{array}$ & $\begin{array}{c}0.314^{* * *} \\
(4.66)\end{array}$ & $\begin{array}{c}0.364^{* * *} \\
(4.20)\end{array}$ \\
\hline Years of previous unemployment between the two previous jobs & $\begin{array}{c}-0.038^{* * *} \\
(5.01)\end{array}$ & $\begin{array}{c}-0.053^{* * *} \\
(5.34)\end{array}$ & $\begin{array}{c}-0.028^{* * *} \\
(3.96)\end{array}$ & $\begin{array}{c}-0.029^{* * *} \\
(5.11)\end{array}$ & $\begin{array}{c}-0.027^{* * *} \\
(4.02)\end{array}$ & $\begin{array}{c}-0.025^{* * *} \\
(2.66)\end{array}$ & $\begin{array}{c}-0.043^{* *} \\
(2.03)\end{array}$ & $\begin{array}{c}-0.032 \\
(1.16)\end{array}$ \\
\hline $\begin{array}{l}\text { Number of observations } \\
\text { Pseudo } R^{2} / R^{2}\end{array}$ & $\begin{array}{l}7786 \\
0.387\end{array}$ & $\begin{array}{l}7786 \\
0.085\end{array}$ & $\begin{array}{l}7786 \\
0.074\end{array}$ & $\begin{array}{l}7786 \\
0.100\end{array}$ & $\begin{array}{l}7786 \\
0.191\end{array}$ & $\begin{array}{l}7786 \\
0.292\end{array}$ & $\begin{array}{l}7786 \\
0.345\end{array}$ & $\begin{array}{l}7786 \\
0.369\end{array}$ \\
\hline
\end{tabular}

Source: FACS Morocco 2000

Absolute values of $t$ statistics are in parentheses. Significance levels are respectively $1 \%\left({ }^{* *}\right), 5 \%\left({ }^{* *}\right)$ and $10 \%\left(\left(^{*}\right)\right.$. 
Table 4. Fixed effects, OLS and quantile regressions with firm factors of the log monthly earnings

\begin{tabular}{|c|c|c|c|c|c|c|c|c|c|}
\hline \multirow[t]{2}{*}{ Variables } & \multirow{2}{*}{$\begin{array}{l}\text { Fixed } \\
\text { effects }\end{array}$} & \multirow[t]{2}{*}{ OLS } & \multicolumn{7}{|c|}{ Quantile regressions } \\
\hline & & & 0.05 & 0.10 & 0.25 & 0.50 & 0.75 & 0.90 & 0.95 \\
\hline Constant & $\begin{array}{l}7.021^{* * *} \\
(247.36)\end{array}$ & $\begin{array}{l}7.075^{* * *} \\
(245.12)\end{array}$ & $\begin{array}{l}6.963^{* * *} \\
(133.73)\end{array}$ & $\begin{array}{l}7.103^{* * *} \\
(216.69)\end{array}$ & $\begin{array}{l}7.147^{* * *} \\
(308.69)\end{array}$ & $\begin{array}{l}7.128^{* * *} \\
(303.22)\end{array}$ & $\begin{array}{l}7.219^{* * *} \\
(217.80)\end{array}$ & $\begin{array}{l}7.343^{* * *} \\
(136.05)\end{array}$ & $\begin{array}{c}7.382^{* * *} \\
(94.66)\end{array}$ \\
\hline Dummy for being female & $\begin{array}{c}-0.136^{* * *} \\
(12.76)\end{array}$ & $\begin{array}{c}-0.134^{* * *} \\
(12.01)\end{array}$ & $\begin{array}{c}-0.075^{* * *} \\
(4.01)\end{array}$ & $\begin{array}{c}-0.065^{* * *} \\
(5.30)\end{array}$ & $\begin{array}{c}-0.075^{* * *} \\
(8.34)\end{array}$ & $\begin{array}{c}-0.089^{* * *} \\
(9.85)\end{array}$ & $\begin{array}{c}-0.136^{* * *} \\
(11.12)\end{array}$ & $\begin{array}{c}-0.172^{* * *} \\
(9.00)\end{array}$ & $\begin{array}{c}-0.183^{* * *} \\
(6.46)\end{array}$ \\
\hline Number of children & $\begin{array}{l}0.006^{*} \\
(1.81)\end{array}$ & $\begin{array}{l}0.005 \\
(1.28)\end{array}$ & $\begin{array}{c}-0.005 \\
(0.80)\end{array}$ & $\begin{array}{c}-0.003 \\
(0.63)\end{array}$ & $\begin{array}{l}0.004 \\
(1.21)\end{array}$ & $\begin{array}{c}0.007^{* *} \\
(2.09)\end{array}$ & $\begin{array}{c}0.012^{* * *} \\
(2.94)\end{array}$ & $\begin{array}{l}0.005 \\
(0.87)\end{array}$ & $\begin{array}{l}0.013 \\
(1.48)\end{array}$ \\
\hline Years of completed schooling & $\begin{array}{c}-0.030^{* * *} \\
(8.68)\end{array}$ & $\begin{array}{c}-0.026^{* * *} \\
(7.57)\end{array}$ & $\begin{array}{c}-0.007 \\
(1.03)\end{array}$ & $\begin{array}{l}-0.005 \\
(1.35)\end{array}$ & $\begin{array}{c}-0.016^{* * *} \\
(5.64)\end{array}$ & $\begin{array}{c}-0.027^{* * *} \\
(9.75)\end{array}$ & $\begin{array}{c}-0.034^{* * *} \\
(8.62)\end{array}$ & $\begin{array}{c}-0.030^{* * *} \\
(4.91)\end{array}$ & $\begin{array}{c}-0.031^{* * *} \\
(3.42)\end{array}$ \\
\hline$(\text { Years of completed schooling })^{2} / 100$ & $\begin{array}{c}0.564^{* * *} \\
(27.69)\end{array}$ & $\begin{array}{c}0.524^{* * *} \\
(26.26)\end{array}$ & $\begin{array}{c}0.167^{* * *} \\
(4.52)\end{array}$ & $\begin{array}{c}0.161^{* * *} \\
(7.08)\end{array}$ & $\begin{array}{c}0.289^{* * * *} \\
(18.11)\end{array}$ & $\begin{array}{c}0.479^{* * *} \\
(29.46)\end{array}$ & $\begin{array}{c}0.633^{* * *} \\
(27.67)\end{array}$ & $\begin{array}{c}0.728^{* * *} \\
(20.46)\end{array}$ & $\begin{array}{c}0.807^{* * *} \\
(15.11)\end{array}$ \\
\hline Years of potential experience & $\begin{array}{c}0.031^{* * *} \\
(16.95)\end{array}$ & $\begin{array}{c}0.031^{* * *} \\
(16.29)\end{array}$ & $\begin{array}{c}0.013^{* * *} \\
(3.83)\end{array}$ & $\begin{array}{c}0.011^{* * *} \\
(5.21)\end{array}$ & $\begin{array}{c}0.018^{* * *} \\
(12.08)\end{array}$ & $\begin{array}{c}0.029^{* * *} \\
(18.75)\end{array}$ & $\begin{array}{c}0.034^{* * *} \\
(15.98)\end{array}$ & $\begin{array}{c}0.038^{* * *} \\
(11.18)\end{array}$ & $\begin{array}{c}0.040^{* * *} \\
(7.91)\end{array}$ \\
\hline$(\text { Years of potential experience })^{2} / 100$ & $\begin{array}{c}-0.041^{* * *} \\
(12.24)\end{array}$ & $\begin{array}{c}-0.043^{* * *} \\
(12.03)\end{array}$ & $\begin{array}{c}-0.020^{* * *} \\
(3.27)\end{array}$ & $\begin{array}{c}-0.017^{* * *} \\
(4.54)\end{array}$ & $\begin{array}{c}-0.029^{* * *} \\
(10.47)\end{array}$ & $\begin{array}{c}-0.046^{* * *} \\
(15.68)\end{array}$ & $\begin{array}{c}-0.051^{* * *} \\
(12.48)\end{array}$ & $\begin{array}{c}-0.047^{* * *} \\
(7.72)\end{array}$ & $\begin{array}{c}-0.047^{* * *} \\
(5.12)\end{array}$ \\
\hline Years of tenure in the current firm & $\begin{array}{c}0.024^{* * *} \\
(9.16)\end{array}$ & $\begin{array}{c}0.013^{* * *} \\
(5.58)\end{array}$ & $\begin{array}{c}0.014^{* * *} \\
(3.77)\end{array}$ & $\begin{array}{c}0.011^{* * *} \\
(4.60)\end{array}$ & $\begin{array}{c}0.008^{* * *} \\
(4.36)\end{array}$ & $\begin{array}{c}0.008^{* * *} \\
(4.17)\end{array}$ & $\begin{array}{c}0.008^{* * *} \\
(3.30)\end{array}$ & $\begin{array}{l}0.006 \\
(1.35)\end{array}$ & $\begin{array}{c}0.014^{* * *} \\
(2.75)\end{array}$ \\
\hline$(\text { Years of tenure in the current firm })^{2} / 100$ & $\begin{array}{c}-0.029^{* * *} \\
(3.43)\end{array}$ & $\begin{array}{l}0.003 \\
(0.39)\end{array}$ & $\begin{array}{c}-0.003 \\
(0.28)\end{array}$ & $\begin{array}{l}0.002 \\
(0.21)\end{array}$ & $\begin{array}{l}0.011^{*} \\
(1.72)\end{array}$ & $\begin{array}{c}0.021^{* * *} \\
(3.24)\end{array}$ & $\begin{array}{c}0.026^{* * *} \\
(2.89)\end{array}$ & $\begin{array}{c}0.037^{* *} \\
(2.24)\end{array}$ & $\begin{array}{l}0.022 \\
(1.29)\end{array}$ \\
\hline Number of preceding jobs & $\begin{array}{c}0.011^{* * *} \\
(3.43)\end{array}$ & $\begin{array}{c}0.018^{* * *} \\
(5.73)\end{array}$ & $\begin{array}{l}0.011^{*} \\
(1.65)\end{array}$ & $\begin{array}{c}0.012^{* * *} \\
(2.60)\end{array}$ & $\begin{array}{c}0.017^{* * *} \\
(6.00)\end{array}$ & $\begin{array}{c}0.020^{* * *} \\
(7.61)\end{array}$ & $\begin{array}{c}0.025^{* * *} \\
(7.54)\end{array}$ & $\begin{array}{c}0.028^{* * *} \\
(5.56)\end{array}$ & $\begin{array}{c}0.032^{* * *} \\
(4.60)\end{array}$ \\
\hline Dummy for received formal training in the previous job & $\begin{array}{c}0.321^{* * *} \\
(9.91)\end{array}$ & $\begin{array}{c}0.282^{* * *} \\
(8.18)\end{array}$ & $\begin{array}{l}0.093 \\
(1.61)\end{array}$ & $\begin{array}{c}0.135^{* * *} \\
(3.46)\end{array}$ & $\begin{array}{c}0.128^{* * *} \\
(4.63)\end{array}$ & $\begin{array}{c}0.373^{* * *} \\
(13.32)\end{array}$ & $\begin{array}{c}0.399^{* * *} \\
(10.60)\end{array}$ & $\begin{array}{c}0.327^{* * *} \\
(5.69)\end{array}$ & $\begin{array}{c}0.342^{* * *} \\
(4.04)\end{array}$ \\
\hline Years of previous unemployment between the two previous jobs & $\begin{array}{c}-0.030^{* * *} \\
(4.36)\end{array}$ & $\begin{array}{c}-0.039^{* * *} \\
(5.37)\end{array}$ & $\begin{array}{c}-0.059^{* * *} \\
(6.15)\end{array}$ & $\begin{array}{c}-0.021^{* * *} \\
(3.13)\end{array}$ & $\begin{array}{c}-0.026^{* * *} \\
(5.22)\end{array}$ & $\begin{array}{c}-0.027^{* * *} \\
(4.51)\end{array}$ & $\begin{array}{c}-0.026^{* * *} \\
(2.82)\end{array}$ & $\begin{array}{c}-0.041^{* *} \\
(2.54)\end{array}$ & $\begin{array}{c}-0.030^{* *} \\
(2.31)\end{array}$ \\
\hline $\begin{array}{l}\text { Number of observations } \\
\text { Pseudo } \mathrm{R}^{2} / \mathrm{R}^{2}\end{array}$ & $\begin{array}{l}7786 \\
0.383\end{array}$ & $\begin{array}{l}7786 \\
0.436\end{array}$ & $\begin{array}{l}7786 \\
0.129\end{array}$ & $\begin{array}{l}7786 \\
0.117\end{array}$ & $\begin{array}{l}7786 \\
0.139\end{array}$ & $\begin{array}{l}7786 \\
0.223\end{array}$ & $\begin{array}{l}7786 \\
0.322\end{array}$ & $\begin{array}{l}7786 \\
0.374\end{array}$ & $\begin{array}{l}7786 \\
0.392\end{array}$ \\
\hline
\end{tabular}

Source: FACS Morocco 2000

Absolute values of $t$ statistics are in parentheses. Significance levels are respectively $1 \%\left({ }^{* *}\right), 5 \%\left(^{* *}\right)$ and $10 \%\left({ }^{*}\right)$. 
Table 5. Gender-specific quantile and OLS regressions with firm factors of the log monthly earnings

\begin{tabular}{|c|c|c|c|c|c|c|c|c|c|c|c|c|}
\hline \multirow[t]{3}{*}{ Variables } & \multicolumn{10}{|c|}{ Quantile regressions } & \multirow{2}{*}{\multicolumn{2}{|c|}{ Fixed effects }} \\
\hline & \multicolumn{2}{|c|}{0.1} & \multicolumn{2}{|c|}{0.25} & \multicolumn{2}{|c|}{0.5} & \multicolumn{2}{|c|}{0.75} & \multicolumn{2}{|c|}{0.9} & & \\
\hline & Men & Women & Men & Women & Men & Women & Men & Women & Men & Women & Men & Women \\
\hline Constant & $\begin{array}{l}7.000^{* * * *} \\
(163.43)\end{array}$ & $\begin{array}{l}7.119^{* * *} \\
(184.82)\end{array}$ & $\begin{array}{l}7.022^{* * *} \\
(216.70)\end{array}$ & $\begin{array}{l}7.234^{* * *} \\
(258.70)\end{array}$ & $\begin{array}{l}6.986^{* * *} \\
(183.72)\end{array}$ & $\begin{array}{l}7.252^{* * *} \\
(242.65)\end{array}$ & $\begin{array}{l}7.005^{* * *} \\
(112.64)\end{array}$ & $\begin{array}{l}7.278^{* * *} \\
(219.19)\end{array}$ & $\begin{array}{l}7.200^{* * *} \\
(77.48)\end{array}$ & $\begin{array}{l}7.340^{* * *} \\
(110.24)\end{array}$ & $\begin{array}{l}6.921^{* * *} \\
(169.64)\end{array}$ & $\begin{array}{l}7.059^{* * * *} \\
(183.19)\end{array}$ \\
\hline Number of children & $\begin{array}{l}-0.001 \\
(0.23)\end{array}$ & $\begin{array}{l}0.001 \\
(0.19)\end{array}$ & $\begin{array}{l}-0.004 \\
(1.13)\end{array}$ & $\begin{array}{l}0.016^{* * *} \\
(2.84)\end{array}$ & $\begin{array}{l}-0.007 \\
(1.59)\end{array}$ & $\begin{array}{l}0.030^{* * *} \\
(5.32)\end{array}$ & $\begin{array}{l}0.001 \\
(0.08)\end{array}$ & $\begin{array}{l}0.031^{* * *} \\
(5.32)\end{array}$ & $\begin{array}{l}-0.003 \\
(0.29)\end{array}$ & $\begin{array}{l}0.033^{* * *} \\
(3.20)\end{array}$ & $\begin{array}{l}-0.001 \\
(0.21)\end{array}$ & $\begin{array}{l}0.028^{* * *} \\
(4.29)\end{array}$ \\
\hline Years of completed schooling & $\begin{array}{l}-0.015^{* * *} \\
(2.60)\end{array}$ & $\begin{array}{l}0.006 \\
(1.32)\end{array}$ & $\begin{array}{l}-0.020^{* * *} \\
(4.75)\end{array}$ & $\begin{array}{l}-0.007^{* *} \\
(2.01)\end{array}$ & $\begin{array}{l}-0.029^{* * *} \\
(6.42)\end{array}$ & $\begin{array}{l}-0.015^{* * *} \\
(3.77)\end{array}$ & $\begin{array}{l}-0.023^{* * *} \\
(3.28)\end{array}$ & $\begin{array}{l}-0.027^{* * *} \\
(6.17)\end{array}$ & $\begin{array}{l}-0.025^{* *} \\
(2.56)\end{array}$ & $\begin{array}{l}-0.026^{* * *} \\
(3.01)\end{array}$ & $\begin{array}{l}-0.032^{* * *} \\
(6.36)\end{array}$ & $\begin{array}{l}-0.021^{* * *} \\
(4.08)\end{array}$ \\
\hline (Years of completed schooling $)^{2} / 100$ & $\begin{array}{l}0.263^{* * *} \\
(7.91)\end{array}$ & $\begin{array}{l}0.049^{*} \\
(1.76)\end{array}$ & $\begin{array}{l}0.368^{* * *} \\
(15.53)\end{array}$ & $\begin{array}{l}0.149^{* * *} \\
(6.88)\end{array}$ & $\begin{array}{l}0.563^{* * *} \\
(22.01)\end{array}$ & $\begin{array}{l}0.282^{* * *} \\
(11.64)\end{array}$ & $\begin{array}{l}0.667^{* * *} \\
(16.82)\end{array}$ & $\begin{array}{l}0.469^{* * *} \\
(17.35)\end{array}$ & $\begin{array}{l}0.771^{* * *} \\
(13.35)\end{array}$ & $\begin{array}{l}0.615^{* * *} \\
(11.34)\end{array}$ & $\begin{array}{l}0.622^{* * *} \\
(21.61)\end{array}$ & $\begin{array}{l}0.419^{* * *} \\
(13.21)\end{array}$ \\
\hline Years of potential experience & $\begin{array}{l}0.018^{* * *} \\
(6.25)\end{array}$ & $\begin{array}{l}0.001 \\
(0.36)\end{array}$ & $\begin{array}{l}0.024^{* * * *} \\
(11.00)\end{array}$ & $\begin{array}{l}0.010^{* * *} \\
(4.93)\end{array}$ & $\begin{array}{l}0.033^{* * *} \\
(12.66)\end{array}$ & $\begin{array}{l}0.024^{* * *} \\
(10.30)\end{array}$ & $\begin{array}{l}0.039^{* * * *} \\
(9.55)\end{array}$ & $\begin{array}{l}0.027^{* * *} \\
(11.05)\end{array}$ & $\begin{array}{l}0.035^{* * *} \\
(5.76)\end{array}$ & $\begin{array}{l}0.028^{* * *} \\
(6.19)\end{array}$ & $\begin{array}{l}0.031^{* * * *} \\
(11.53)\end{array}$ & $\begin{array}{l}0.029^{* * *} \\
(10.04)\end{array}$ \\
\hline$(\text { Years of potential experience })^{2} / 100$ & $\begin{array}{l}-0.026^{* * *} \\
(5.11)\end{array}$ & $\begin{array}{l}-0.002 \\
(0.38)\end{array}$ & $\begin{array}{l}-0.034^{* * *} \\
(8.65)\end{array}$ & $\begin{array}{l}-0.023^{* * *} \\
(5.48)\end{array}$ & $\begin{array}{l}-0.043^{* * *} \\
(9.22)\end{array}$ & $\begin{array}{l}-0.047^{* * *} \\
(10.15)\end{array}$ & $\begin{array}{l}-0.048^{* * *} \\
(6.68)\end{array}$ & $\begin{array}{l}-0.049^{* * *} \\
(9.72)\end{array}$ & $\begin{array}{l}-0.032^{* * *} \\
(3.07)\end{array}$ & $\begin{array}{l}-0.038^{* * *} \\
(4.34)\end{array}$ & $\begin{array}{l}-0.036^{* * *} \\
(7.78)\end{array}$ & $\begin{array}{l}-0.048^{* * *} \\
(8.30)\end{array}$ \\
\hline Years of tenure in the current firm & $\begin{array}{l}0.013^{* * *} \\
(4.10)\end{array}$ & $\begin{array}{l}0.016^{* * * *} \\
(5.14)\end{array}$ & $\begin{array}{l}0.011^{* * *} \\
(4.52)\end{array}$ & $\begin{array}{l}0.009^{* * *} \\
(3.71)\end{array}$ & $\begin{array}{l}0.016^{* * *} \\
(5.37)\end{array}$ & $\begin{array}{l}-0.002 \\
(0.89)\end{array}$ & $\begin{array}{l}0.016^{* * *} \\
(3.75)\end{array}$ & $\begin{array}{l}0.005^{*} \\
(1.68)\end{array}$ & $\begin{array}{l}0.025^{* * *} \\
(4.00)\end{array}$ & $\begin{array}{l}0.002 \\
(0.30)\end{array}$ & $\begin{array}{l}0.032^{* * *} \\
(9.02)\end{array}$ & $\begin{array}{l}0.009^{* *} \\
(2.37)\end{array}$ \\
\hline$(\text { Years of tenure in the current firm })^{2} / 100$ & $\begin{array}{l}-0.006 \\
(0.58)\end{array}$ & $\begin{array}{l}-0.011 \\
(1.04)\end{array}$ & $\begin{array}{l}0.001 \\
(0.08)\end{array}$ & $\begin{array}{l}0.002 \\
(0.17)\end{array}$ & $\begin{array}{l}-0.007 \\
(0.69)\end{array}$ & $\begin{array}{l}0.062^{* * *} \\
(6.44)\end{array}$ & $\begin{array}{l}-0.006 \\
(0.38)\end{array}$ & $\begin{array}{l}0.047^{* * *} \\
(4.29)\end{array}$ & $\begin{array}{l}-0.036^{*} \\
(1.70)\end{array}$ & $\begin{array}{l}0.062^{* * *} \\
(3.30)\end{array}$ & $\begin{array}{l}-0.059^{* * *} \\
(5.16)\end{array}$ & $\begin{array}{l}0.033^{* *} \\
(2.34)\end{array}$ \\
\hline Number of preceding jobs & $\begin{array}{l}0.001 \\
(0.28)\end{array}$ & $\begin{array}{l}0.039^{* * *} \\
(5.89)\end{array}$ & $\begin{array}{l}0.008^{* *} \\
(2.17)\end{array}$ & $\begin{array}{l}0.029^{* * *} \\
(6.94)\end{array}$ & $\begin{array}{l}0.013^{* * * *} \\
(3.39)\end{array}$ & $\begin{array}{l}0.022^{* * *} \\
(5.29)\end{array}$ & $\begin{array}{l}0.023^{* * *} \\
(4.08)\end{array}$ & $\begin{array}{l}0.026^{* * *} \\
(6.08)\end{array}$ & $\begin{array}{l}0.030^{* * *} \\
(3.92)\end{array}$ & $\begin{array}{l}0.032^{* * *} \\
(3.97)\end{array}$ & $\begin{array}{l}0.012^{* * *} \\
(2.74)\end{array}$ & $\begin{array}{l}0.015^{* * *} \\
(2.78)\end{array}$ \\
\hline Dummy for received formal training in the previous job & $\begin{array}{l}0.116^{* *} \\
(2.42)\end{array}$ & $\begin{array}{l}0.115^{* *} \\
(2.19)\end{array}$ & $\begin{array}{l}0.179^{* * *} \\
(4.89)\end{array}$ & $\begin{array}{l}0.046 \\
(1.12)\end{array}$ & $\begin{array}{l}0.352^{* * *} \\
(8.51)\end{array}$ & $\begin{array}{l}0.128^{* * *} \\
(2.82)\end{array}$ & $\begin{array}{l}0.342^{* * *} \\
(5.44)\end{array}$ & $\begin{array}{l}0.297^{* * *} \\
(6.11)\end{array}$ & $\begin{array}{l}0.272^{* * *} \\
(2.95)\end{array}$ & $\begin{array}{l}0.188^{* *} \\
(2.35)\end{array}$ & $\begin{array}{l}0.364^{* * *} \\
(8.36)\end{array}$ & $\begin{array}{l}0.246^{* * *} \\
(4.34)\end{array}$ \\
\hline Years of previous unemployment between the two previous jobs & $\begin{array}{l}-0.021^{* *} \\
(1.99) \\
\end{array}$ & $\begin{array}{l}-0.022^{* * *} \\
(3.25)\end{array}$ & $\begin{array}{l}-0.036^{* * *} \\
(4.56) \\
\end{array}$ & $\begin{array}{l}-0.031^{* * *} \\
(5.37) \\
\end{array}$ & $\begin{array}{l}-0.027^{* * *} \\
(2.92) \\
\end{array}$ & $\begin{array}{l}-0.026^{* * *} \\
(3.64)\end{array}$ & $\begin{array}{l}-0.051^{\text {*** }} \\
(2.93)\end{array}$ & $\begin{array}{l}-0.022^{* * *} \\
(2.65) \\
\end{array}$ & $\begin{array}{l}-0.043^{*} \\
(1.82) \\
\end{array}$ & $\begin{array}{l}-0.032^{* * *} \\
(2.85) \\
\end{array}$ & $\begin{array}{c}-0.038^{* * *} \\
(37.97) \\
\end{array}$ & $\begin{array}{r}-0.017^{* *} \\
(25.90) \\
\end{array}$ \\
\hline Number of observations & 4675 & 3111 & 4675 & 3111 & 4675 & 3111 & 4675 & 3111 & 4675 & 3111 & 4675 & 3111 \\
\hline Pseudo $\mathrm{R}^{2} / \mathrm{R}^{2}$ & 0.122 & 0.122 & 0.159 & 0.115 & 0.255 & 0.158 & 0.327 & 0.275 & 0.378 & 0.334 & 0.398 & 0.286 \\
\hline
\end{tabular}

Source: FACS Morocco 2000

Absolute values of $t$ statistics are in parentheses. Significance levels are respectively $1 \%\left({ }^{* *}\right), 5 \%\left(^{* *}\right)$ and $10 \%\left({ }^{*}\right)$. 
Table 6. Mean and quantile decompositions of the gender earnings gap

\begin{tabular}{|c|c|c|c|c|c|c|}
\hline \multirow[t]{2}{*}{ Type of decomposition } & \multicolumn{2}{|c|}{ Difference in characteristics } & \multicolumn{2}{|c|}{ Difference in coefficients } & \multicolumn{2}{|c|}{ Total difference } \\
\hline & No firm factors & With firm factors & No firm factors & With firm factors & No firm factors & With firm factors \\
\hline $\begin{array}{l}\text { Oaxaca-Blinder decomposition } \\
\text { Mean }\end{array}$ & $\begin{array}{c}0.1333 \\
(0.0100)\end{array}$ & $\begin{array}{c}0.1288 \\
(0.0108)\end{array}$ & $\begin{array}{c}0.1108 \\
(0.0129)\end{array}$ & $\begin{array}{c}0.1153 \\
(0.0129)\end{array}$ & $\begin{array}{c}0.2441 \\
(0.0124)\end{array}$ & $\begin{array}{c}0.2441 \\
(0.0124)\end{array}$ \\
\hline Machado-Mata decomposition & & & & & & \\
\hline Percentile 10 & $\begin{array}{c}0.0556 \\
(0.0038)\end{array}$ & $\begin{array}{c}0.0502 \\
(0.0052)\end{array}$ & $\begin{array}{c}0.0692 \\
(0.0072)\end{array}$ & $\begin{array}{c}0.0734 \\
(0.0039)\end{array}$ & $\begin{array}{c}0.1248 \\
(0.0048)\end{array}$ & $\begin{array}{c}0.1237 \\
(0.0076)\end{array}$ \\
\hline Percentile 25 & $\begin{array}{c}0.0583 \\
(0.0033)\end{array}$ & $\begin{array}{c}0.0622 \\
(0.0031)\end{array}$ & $\begin{array}{c}0.0996 \\
(0.0088)\end{array}$ & $\begin{array}{c}0.0994 \\
(0.0071)\end{array}$ & $\begin{array}{c}0.1580 \\
(0.0108)\end{array}$ & $\begin{array}{c}0.1617 \\
(0.0082)\end{array}$ \\
\hline Percentile 50 & $\begin{array}{l}0.0945 \\
(0.0055)\end{array}$ & $\begin{array}{c}0.1032 \\
(0.0108)\end{array}$ & $\begin{array}{c}0.1370 \\
(0.0086)\end{array}$ & $\begin{array}{l}0.1318 \\
(0.0036)\end{array}$ & $\begin{array}{c}0.2316 \\
(0.0124)\end{array}$ & $\begin{array}{c}0.2351 \\
(0.0090)\end{array}$ \\
\hline Percentile 75 & $\begin{array}{c}0.1475 \\
(0.0096)\end{array}$ & $\begin{array}{c}0.1372 \\
(0.0070)\end{array}$ & $\begin{array}{c}0.1888 \\
(0.0094)\end{array}$ & $\begin{array}{c}0.1900 \\
(0.0166)\end{array}$ & $\begin{array}{c}0.3364 \\
(0.0145)\end{array}$ & $\begin{array}{c}0.3273 \\
(0.0182)\end{array}$ \\
\hline Percentile 90 & $\begin{array}{c}0.2191 \\
(0.0148)\end{array}$ & $\begin{array}{c}0.1825 \\
(0.0146)\end{array}$ & $\begin{array}{c}0.1689 \\
(0.0181)\end{array}$ & $\begin{array}{c}0.1978 \\
(0.0132)\end{array}$ & $\begin{array}{c}0.3881 \\
(0.0079)\end{array}$ & $\begin{array}{c}0.3803 \\
(0.0099)\end{array}$ \\
\hline
\end{tabular}

Source: FACS Morocco 2000.

Note: For the quantile decomposition, standard errors in parentheses are obtained with 50 replications of the decomposition. 
Table 7. Predicted earnings growth and gender effect

\begin{tabular}{|c|c|c|c|c|c|}
\hline \multirow{2}{*}{$\begin{array}{l}\text { Dependent variable : } \\
\text { Log earnings } 1999 \text { - Log earnings } 1998\end{array}$} & \multicolumn{4}{|c|}{ Quartile of earnings in 1998} & \multirow[b]{2}{*}{ Mean value } \\
\hline & 1 & 2 & 3 & 4 & \\
\hline \multicolumn{6}{|l|}{ (1) No control variables } \\
\hline $\operatorname{Men}(n=4302)$ & 4.31 & 2.43 & 3.52 & 2.59 & 3.17 \\
\hline Women $(n=2759)$ & 5.27 & 2.23 & 3.13 & 2.23 & 3.47 \\
\hline Difference & -0.96 & 0.20 & 0.39 & 0.36 & -0.30 \\
\hline \multicolumn{6}{|c|}{ (2) Control variables: potential experience, potential experience squared } \\
\hline Men & 4.53 & 2.53 & 4.00 & 2.70 & 3.38 \\
\hline Women & 4.76 & 2.36 & 2.66 & 1.96 & 3.23 \\
\hline Difference & -0.23 & 0.17 & 1.34 & 0.74 & 0.15 \\
\hline \multicolumn{6}{|c|}{$\begin{array}{l}\text { (3) Control variables: same as }(2)+\text { number of children, years of schooling, tenure in the current firm, number of } \\
\text { preceding jobs, formal training in the previous job, years of previous unemployment between the two previous jobs }\end{array}$} \\
\hline Men & 4.81 & 3.07 & 4.11 & 3.03 & 3.41 \\
\hline Women & 5.55 & 2.81 & 3.05 & 0.93 & 3.38 \\
\hline Difference & -0.74 & 0.26 & 1.06 & 2.1 & 0.03 \\
\hline \multicolumn{6}{|c|}{ (4) Control variables: same as (3) + occupational status } \\
\hline Men & 5.69 & 3.63 & 4.18 & 2.86 & 3.40 \\
\hline Women & 6.86 & 3.30 & 3.01 & 0.76 & 3.37 \\
\hline Difference & -1.17 & 0.33 & 1.17 & 2.1 & 0.03 \\
\hline
\end{tabular}

Source: FACS Morocco 2000. 
Table 8. Effects of firm characteristics on the within-firm gender earnings gap

\begin{tabular}{|c|c|c|c|c|c|}
\hline \multirow[t]{2}{*}{ Variables } & & \multicolumn{2}{|c|}{$\begin{array}{l}\text { Control for the effect of } \\
\text { occupation on earnings }\end{array}$} & \multicolumn{2}{|c|}{$\begin{array}{l}\text { No control for the effect } \\
\text { of occupation on earnings }\end{array}$} \\
\hline & & $(1)$ & $(2)$ & (3) & $(4)$ \\
\hline \multirow[t]{11}{*}{ Sectoral dummies (Ref: Garment firms) } & Food & $\begin{array}{l}0.025 \\
(0.63)\end{array}$ & $\begin{array}{c}-0.008 \\
(0.16)\end{array}$ & $\begin{array}{c}-0.008 \\
(0.18)\end{array}$ & -0.039 \\
\hline & Textile & $0.065 * *$ & $0.067 *$ & 0.039 & 0.038 \\
\hline & & $(2.04)$ & $(1.77)$ & $(1.07)$ & $(0.85)$ \\
\hline & Leather & 0.030 & 0.034 & -0.005 & 0.009 \\
\hline & & $(0.76)$ & $(0.66)$ & $(0.11)$ & $(0.17)$ \\
\hline & Electrical & $0.190 * * *$ & $0.190^{* *}$ & $0.131 *$ & 0.122 \\
\hline & & $(2.72)$ & $(2.56)$ & $(1.66)$ & $(1.42)$ \\
\hline & Chemicals & -0.049 & -0.079 & -0.092 & $-0.131 *$ \\
\hline & & $(0.98)$ & $(1.35)$ & $(1.61)$ & $(1.85)$ \\
\hline & Plastics & 0.019 & 0.020 & -0.031 & -0.038 \\
\hline & & $(0.35)$ & $(0.30)$ & $(0.47)$ & $(0.46)$ \\
\hline \multirow{2}{*}{\multicolumn{2}{|c|}{ Primarily exporting firms }} & -0.029 & -0.013 & -0.040 & -0.025 \\
\hline & & $(0.99)$ & $(0.36)$ & $(1.19)$ & $(0.57)$ \\
\hline \multirow{2}{*}{\multicolumn{2}{|c|}{ Number of local competitors for the principal product }} & 0.000 & 0.000 & 0.000 & 0.000 \\
\hline & & $(0.26)$ & $(0.29)$ & $(0.94)$ & $(0.96)$ \\
\hline \multirow{2}{*}{\multicolumn{2}{|c|}{ Market share }} & 0.001 & $0.001 *$ & 0.001 & 0.001 \\
\hline & & $(1.28)$ & $(1.83)$ & $(1.06)$ & $(1.10)$ \\
\hline \multirow{2}{*}{\multicolumn{2}{|c|}{ Share of female employees }} & 0.002 & 0.002 & 0.001 & 0.001 \\
\hline & & $(0.93)$ & $(1.20)$ & $(0.45)$ & $(0.33)$ \\
\hline \multicolumn{2}{|c|}{ Firm size } & $0.045^{* * *}$ & $0.040 * *$ & 0.020 & 0.013 \\
\hline \multicolumn{2}{|c|}{$(1:<50$ employees, $2: 50<$ employees $<150,3:$ employees $>150)$} & $(2.63)$ & $(2.01)$ & $(1.07)$ & $(0.56)$ \\
\hline \multirow{2}{*}{\multicolumn{2}{|c|}{ Are the employees unionised? ( 1 if yes) }} & 0.017 & 0.047 & -0.023 & 0.018 \\
\hline & & $(0.33)$ & $(0.85)$ & $(0.31)$ & $(0.20)$ \\
\hline \multirow{2}{*}{\multicolumn{2}{|c|}{ Share of unionised employees }} & -0.073 & -0.072 & -0.049 & -0.069 \\
\hline & & $(1.18)$ & $(1.27)$ & $(0.55)$ & $(0.72)$ \\
\hline \multirow{2}{*}{\multicolumn{2}{|c|}{ Qualified employees being dominant occupation (1 if yes) }} & -0.027 & -0.037 & -0.013 & -0.037 \\
\hline & & $(1.06)$ & $(1.24)$ & $(0.46)$ & $(1.09)$ \\
\hline \multirow{2}{*}{\multicolumn{2}{|c|}{$\begin{array}{l}\text { Share of managers higher than } 10 \% \text { of the total employees } \\
\text { (1 if yes) }\end{array}$}} & -0.069 & -0.077 & $-0.143^{* * *}$ & $-0.174 * *$ \\
\hline & & $(1.59)$ & $(1.42)$ & $(2.83)$ & $(2.57)$ \\
\hline \multicolumn{2}{|c|}{ Highly labour intensive firms in 1998} & 0.066 & 0.084 & $0.094 *$ & $0.112^{*}$ \\
\hline \multicolumn{2}{|c|}{ ( 1 if labour costs $>75 \%$ total costs) } & $(1.44)$ & $(1.46)$ & $(1.80)$ & $(1.75)$ \\
\hline \multirow{2}{*}{\multicolumn{2}{|c|}{ Firms with more than $75 \%$ foreign owned ( 1 if yes) }} & $0.172^{* *}$ & $0.152^{* *}$ & $0.155^{*}$ & 0.137 \\
\hline & & $(2.28)$ & $(2.00)$ & $(1.86)$ & $(1.65)$ \\
\hline \multirow{2}{*}{\multicolumn{2}{|c|}{ Profitable firms ( 1 if yes) }} & -0.032 & -0.019 & -0.026 & -0.033 \\
\hline & & $(1.21)$ & $(0.62)$ & $(0.90)$ & $(0.95)$ \\
\hline \multirow{2}{*}{\multicolumn{2}{|c|}{ Share of days lost due to absenteeism }} & & $-0.779 *$ & & $-0.904 * *$ \\
\hline & & & $(1.88)$ & & $(2.17)$ \\
\hline \multirow{2}{*}{\multicolumn{2}{|c|}{ Share of days lost due to strike ${ }^{i}$}} & & $1.269^{*}$ & & $1.151 *$ \\
\hline & & & $(1.93)$ & & $(1.92)$ \\
\hline \multirow{2}{*}{\multicolumn{2}{|c|}{ Share of sales lost due to theft ${ }^{i}$}} & & $9.004 * * *$ & & $9.676^{* * *}$ \\
\hline & & & $(3.39)$ & & $(3.87)$ \\
\hline Share of executives promoted in 1999 & & & $0.833^{* *}$ & & 0.774 \\
\hline & & & $(2.39)$ & & $(1.43)$ \\
\hline Number of on-the-job day-trainees in 19 & & & -0.000 & & -0.000 \\
\hline & & & $(1.17)$ & & $(0.11)$ \\
\hline Constant & & $-0.104 * *$ & $-0.114^{*}$ & -0.020 & 0.004 \\
\hline & & $(2.40)$ & $(1.93)$ & $(0.42)$ & $(0.05)$ \\
\hline Observations & & 442 & 338 & 442 & 338 \\
\hline R-squared & & 0.0950 & 0.1529 & 0.0781 & 0.1281 \\
\hline
\end{tabular}

The dependent variable is the difference in fixed effects $\hat{\phi}_{j}^{m}-\hat{\phi}_{j}^{f}$ in 1999 . Robust t statistics are in parentheses. ${ }^{* *}$, $^{* *}$ and ${ }^{*}$ mean respectively significant at the $1 \%, 5 \%$ and $10 \%$ levels.

(i) Because of the large number of missing values for these firm variables (about $20 \%$ of the firm sample), we use the modified zero-order regression method described in Maddala (1977). Observations with missing information are set to zero and we include in the regression a dummy variable for the missing observations. 